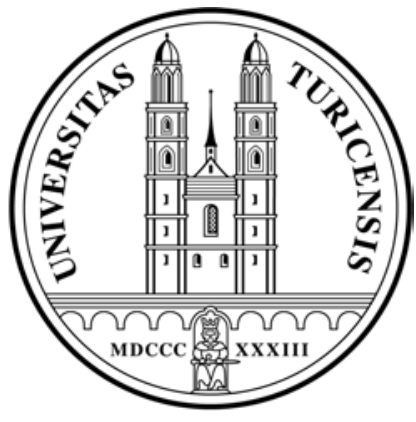

Institute for Empirical Research in Economics

University of Zurich

Working Paper Series

ISSN 1424-0459

Working Paper No. 239

Knight Fever towards an Economics of Awards

Bruno S. Frey

May 2005 


\title{
KNIGHT FEVER \\ TOWARDS AN ECONOMICS OF AWARDS
}

by

Bruno S. Frey*

Institute for Empirical Economic Research. University of Zurich

and

CREMA - Center for Research in Economics, Management and the Arts, Zurich

(this version 25 April 2005)

\begin{abstract}
Awards in the form of orders, medals, decorations and titles are ubiquitous in monarchies and republics, private organizations, not-for-profit and profit-oriented firms. Nevertheless, economists have disregarded this kind of non-material extrinsic incentive.

The demand for awards relies on an individual's desire for distinction, and the supply of awards on the provision of incentives. Relative price and income effects are shown to be identifiable and strong. A number of empirically testable propositions are formulated. As awards are (at least so far) impossible to measure adequately, empirical tests are carried out using the technique of analytic narratives. (93 words)
\end{abstract}

Keywords: Incentives, motivation, awards, orders, distinction, principal-agent

JEL Classification: D23, D73, J22, J33, L22, Z13

\footnotetext{
*Buno S. Frey is Professor of Economics; bsfrey@iew.unizh.ch. Part of this paper was conceived and written while I was a Distinguished Visitor at STICERD, London School of Economics.

I am grateful for the support of Susanne Neckermann when writing the paper, and for enlightening discussions with, and helpful comments to earlier version of the paper to Michael Baurmann, Christine Benesch, Matthias Benz, Tim Besley, Geoffrey Brennan, Reiner Eichenberger, Christoph Engel, Nicolai Foss, Dieter Frey, Hartmut Kliemt, Barbara Krug, Lord Richard Layard, Siegwart Lindenberg, Simon Luechinger, Stephan Meier, Margit Osterloh, Friedrich Schneider, Alois Stutzer and Anna Winestein. I owe the main title to a suggestion by Tim Besley. I thank Rosemary Brown for checking the English.
} 


\section{Introduction}

If an alien were to look at the social life of people here on earth, it would be stunned by the enormous number of awards in the form of orders, medals, decorations, prizes, titles and other honours. It would be hard pressed to find any area of society in which awards are not used. Awards are equally ubiquitous in monarchies as in staunch republics ${ }^{1}$. In the French Republic, for instance, the légion d'honneur plays an important role, and that nation actually confers 3,000 awards annually, which is four times higher than Britain (House of Commons 2004). In the United States, the president and Congress bestow medals, while at the same time purple hearts, bronze and silver stars are handed out quite liberally, and at an increasing rate in the military service (Cowen 2000: 93). It is well known that a flood of orders, medals and titles (such as "Hero of the Soviet Union" or "Hero of Socialist Labour") was handed out in communist countries, such as the Soviet Union or the German Democratic Republic, and that it is typical for both right- and left-wing dictatorships (see the Appendix).

Awards exist not only at the national level. Both the civil and military public sectors are familiar with a large number of awards of all kinds. It is well known that in countries all around the world ${ }^{2}$, the officers are highly decorated; sometimes their entire chests are covered with orders and decorations. In the arts, culture and the media, awards are also of central importance. A few prominent examples are the Academy Awards (Oscars), or the prizes handed out by the film festivals at Cannes, Venice or Berlin, the Emmy award for outstanding achievement in television in the United States, the Grammy award for artistic significance in the field of recording, the Queen Elisabeth International Piano Competition in Brussels, the Booker Prize and the prix Goncourt in literature ${ }^{3}$, or the Pulitzer Prize $e^{4}$. Arts institutions, such as museums, award their supporters titles, such as benefactor or patron ${ }^{5}$. In sports, awards play a major role; there are regular competitions where the winner gets the title Olympic or World champion. In chess, there are International Masters (IM) and Great Masters (GM).

\footnotetext{
${ }^{1}$ The Appendix provides a (probably incomplete) list of "Orders, Decorations and Medals" for selected countries documenting the widespread use of such awards. A more complete list is also given in the article "List of Prizes, Medals, and Awards" in wikipedia (http://en.wikipedia.org).

${ }^{2}$ The only exception seems to be Switzerland, where the (central and cantonal) governments hand out no awards whatsoever in the form of orders, medals or decorations. This applies to the military branch too (but the military managed to be allowed to wear foreign decorations). The Irish do not hand out civil honours, but there are a small number of medals for the personnel of military and emergency services (Phillips 2004: 59).

${ }^{3}$ There are at least 10 other major prizes in British literature, and 5 in French literature, such as the Prix Fémina, Prix Médicis or the Grand Prix du Roman de l'Académie Francaise.

${ }^{4}$ It is awarded in the nine categories Novel, History, Fiction, Poetry, Non-Fiction, Criticism, Telegraphic Reporting, Breaking News Photography and Reporting.

${ }^{5}$ See, for example, Levy (1987), Holden (1993), Nelson (2001), Ginsburgh and van Ours (2003).
} 
Athletes get the honour of being appointed "Sportspersonality of the Year" (the BBC has no less than seven categories), and by being admitted into one of the many Halls of Fame. In September 2004, the International Football Association gave Pelé (Edsen Arantes do Nascimento) and Franz Beckenbauer the "FIFA Centennial Order of Merit", thus establishing that they were the best footballers of the $20^{\text {th }}$ century. In religious organisations, awards are also very important. Take the Catholic Church. It hands out the title monsignore or canon. Furthermore, the Vatican confers many different awards ${ }^{6}$. Canonisation of saints can also be considered as a post mortem award.

It might be thought that academia, as a place of rational interaction, would be an exception. The opposite is true: academia has an elaborate and extensive system of awards. Consider the universities handing out the titles honorary doctor or senator, or professional associations awarding an enormous number of medals, the most important one probably being the Fields Medal in mathematics ${ }^{7}$. And then, of course, there are the Nobel Prizes. Many prestigious fellowships exist in academies of science (e.g. Fellow of the Royal Society FRS, founded in 1660; Fellow of the American Academy of Arts and Sciences, founded in 1780; Fellow of the Royal Society of Edinburgh FRSE, founded, among others, by Adam Smith in 1783; or Fellow of the Academy of Social Sciences in Australia FASSA). Moreover, there is a very complicated system of titles (not always connected to functions), such as that of lecturer, reader, assistant professor, associate professor with or without tenure, full professor, named professor, university professor, distinguished professor etc. An alien looking at earth might well find that academia is (next to the military) one of the places with most awards.

Perhaps even more surprising is the widespread use of awards in the corporate sector of a market economy. Titles are very important and are not always closely related to functions. What manager is not at the very least a vice-president, or even better, a senior vice-president, or first senior vice-president? Awards have recently become very popular in the corporate sector". Firms also commend their own employees for being "Salesman of the Month" or "Employee of the Week"; there seems no limit to the ingenuity to invent ever new awards. The media support this activity by regularly choosing a "Manager of the Month", "Manager of

\footnotetext{
${ }^{6}$ Examples are the Orders of Christ, of the Golden Spur, of Pius, of St. Gregory the Great, of St. Sylvester, of the Holy Sepulchre of Jerusalem etc. (see the Appendix).

7 But there are at least 15 other important prizes in mathematics (http://en.wikipedia.org/wiki/List_of_prizes\%2C_medals\%2C_and_awards).

${ }^{8}$ For instance, the Swiss weekly newspaper Cash presented an (incomplete) list of 59 awards handed out by corporations in Switzerland in one year (2005: 10-11).
} 
the Year" or even "Manager of the Century". Organisations, such as the World Economic Forum, appoint people to the position of "Global Leader of Tomorrow" (1200 persons), and "Young Global Leaders" (1111 persons below 40 years of age). It would be a mistake to attribute this trend simply to "Americanism". In Britain, for instance, the leaders of many large corporations are decorated with orders and titles ${ }^{9}$.

The awards so far mentioned have, of course, many different properties. For some purposes it is necessary to carefully distinguish between, for instance, a (British) Lord from a Knight as the former brings legislative power (he or she becomes a member of the House of Lords) while the latter is purely honorific. There may also be other aspects important to take into account. For instance, prizes that rank books, plays, films and even persons may serve to lower search costs making it easier to know what to watch and read.

Despite the importance of awards in society, economists have largely disregarded them ${ }^{10}$. There are related areas, in particular the economics of reputation and esteem, but the researchers do not focus on the mechanisms through which this utility is achieved, but analyse their consequences. There may be various reasons why economists have not analysed awards. Firstly, awards may be considered to be less efficient as an incentive device, because they are not fungible and difficult to apply marginally. Monetary compensation is in these respects a superior instrument to induce effort. Secondly, awards may just be a reflection of success and high monetary income. An example would be Richard Branson, the founder of Virgin airlines, who was knighted. Thirdly, economists assume that awards as such are of no interest to recipients. After all, they cannot be consumed. The only things of value to individuals are taken to be the ancillary income and the increase in future income induced ${ }^{11}$. There is certainly some truth in this. It has been empirically shown, for instance, that the recipients of Oscars enjoy a huge increase in subsequent income (Nelson et al. 2001). But recipients of the Nobel Prize certainly value the Prize over and above the accompanying or subsequent monetary reward. Conversely, some prizes, medals and awards that are accompanied by huge

\footnotetext{
${ }^{9}$ One example must suffice. The CEO of BP is a Lord (John Browne of Madingley) and he is supported on the board by the knights Sir Ian (Prosser) and Sir Tom (Killop), by Anne Julius, who has a CBE (Commander of the British Empire), and by Michael Miles who has an OBE (Officer of the British Empire) (NZZ 2004: 63).

${ }^{10}$ A search on EconLit, for example, does not give one single reference to orders, medals or decorations.

${ }^{11}$ Another benefit from receiving awards may be that they improve the health of the recipients. It has been calculated that, on average, the actor receiving an Oscar lives four years longer than actors not getting one, see Redelmeier and Singh (2001).
} 
sums of money are nevertheless relatively unknown and have no prestige even within the relevant community, say academia ${ }^{12}$.

This paper argues that there are major differences between awards and monetary compensation, making it worthwhile for some purposes to analyse awards separately. Suffice it at this point in time to mention the following differences:

- The material costs of awards may be very low, or even nil, for the donor, but the value to the recipient may be very high. In this respect (that is without considering the nonmaterial costs of the donor and the costs expended by the recipient), the cost-benefitbalance is therefore unlike that of gifts ${ }^{13}$;

- Accepting an award entails a special relationship, in which the recipient owes (some measure of) loyalty to the donor. The respective contract is, however, tacit, incomplete, and difficult, or impossible, to enforce by the donor;

- Awards are a better incentive instrument than a monetary payment when the recipient's performance can only be vaguely determined;

- Awards are less likely to crowd out the intrinsic motivation of the recipients than monetary compensation;

- Awards are not taxed, while monetary income is.

Economists tend to be rather snobbish about awards. "The Economist" writes about orders as "A ridiculous, outdated system that cannot be improved upon" (2004: 31). But revealed preferences do not seem to support this view. Awards are indeed widespread in our profession. Recipients of Nobel Prizes are (rightly) proud of this honour and do not try to hide it; lobbying activities to get the Nobel Prize are not unheard of (see Nasar (1998) and, more generally, Lindbeck (1985)). Younger American economists crave getting the John Bates Clark Medal of the American Economic Association. The more recently founded European Economic Association hands out a Hicks Medal, and appoints better-known economists to the

\footnotetext{
${ }^{12}$ A pertinent example is a prize awarded to eminent scholars since 1961 by the Italian and Swiss presidents. It goes with 1 Million Swiss Francs (US\$ 770,000), but few persons know about it, and attribute any prestige to it. It is called the Balzan Prize. For a list of other such prizes, see http://en.wikipedia.org/wiki/List_of_prizes\%2C_medals\%2C_and_awards.

${ }^{13}$ As Waldfogel (1993) shows empirically, the recipients of (Christmas)gifts value them much less than the costs to the donor. In the case of awards, the value to the recipient is in general much higher than the costs to the donor.
} 
position of "Fellows". CESifo, one of the leading research institutions in Europe, each year appoints a "Distinguished Fellow". A list of awards given by the national economics associations all over the world would be extremely long. The same applies to the large number of Best Paper Prizes awarded by economics journals (see Coupé (2005)). Many of the most respected economists in Britain have been offered, and accepted, knighthoods, such as Sir John (Hicks), Sir John (Vickers), Sir James (Mirrlees), Sir Partha (Dasgupta), Sir Tony (Atkinson) or Sir Alan (Peacock). Others have achieved an even higher rank of nobility, such as Lord John Maynard Keynes, Lord Lionel Robbins, or Lord Richard Layard.

The whole area of awards is very vague. The semantic is unclear and the various types of awards are not well defined ${ }^{14}$. There is, for example, no clear distinction between orders, decorations or medals, and they can go with or without titles and money. It will be argued in this paper that these unclear distinctions are no accident, but an important feature of awards. The suppliers of awards have an incentive to differentiate awards at many different levels ${ }^{15}$ and to continually create new awards. This makes an analysis difficult because the quality aspect is essential. It is useless to just count the number of orders given because they differ hugely in many respects, most importantly in the appreciation accorded to them. Thus, there is a world of difference between whether a person receives the Most Noble Order of the Garter created in 1348 or an MBE (Member of the Order of the British Empire) created in 1917. At the present state of research, it is therefore not possible to evaluate the extent of awards by a single measure. Moreover, there are serious data limitations. To my knowledge, there is no comprehensive list of awards spanning the different types and levels of awards in the various spheres of society (government, the arts, culture, media, sports, religion, academia, not-for profits and for-profit enterprises), countries and time periods. Only partial, spotty and inconsistent evidence is available from scattered sources. This applies in particular to the many awards given by private institutions, such as non-profit organisations, clubs and firms. Orders given by monarchs or governments are somewhat better documented ${ }^{16}$.

\footnotetext{
${ }^{14}$ This is already reflected in the fact that the word "order" has several different meanings: a mathematical sequence, a command, a religious community or an award. The last two meanings are historically connected. Knights with orders of chivalry (such as the Order of the Holy Sepulchre, founded in 1099, the Templars, founded in 1118, the Order of St. John, 1118, and the Teutonic Order, 1170) wore insignia. Over time, such insignia gained a life of their own, independent of membership to an organisation.

${ }^{15}$ The Order of the British Empire, for instance, has five levels: Knight/Dame Grand Cross, Knight/Dame Commander, Commander, an Officer and a Member; and the German Order of Merit even differentiates between eight different levels, ranging from the Grand Cross Special Class to the simple Medal.

${ }^{16}$ Thus, for example, Phillips (2004) and the House of Commons (2004) give a very useful survey of (part of) the orders in Britain, as well as some limited information about other countries according to conditions at
} 
In view of the bad data situation prohibiting the employment of econometric techniques an alternative technique, analytic narratives (Bates et al. 1998) is applied ${ }^{17}$. This approach allows the researcher to integrate knowledge of different quality, stemming from many different sources. In contrast to econometric approaches requiring consistent data, analytic narratives allow the researcher to combine scattered and inconstant data, and to choose what sources and evidence are useful in supporting or rejecting the proposition being tested.

Analytical narratives are not ideal and have major disadvantages, such as the difficulty of simultaneously accounting for various determinants. While analytic narratives are certainly no substitute for serious econometric analysis, the critique should not be one-sided. In the absence of reasonable data on awards, it seems preferable to resort to many different sources of information rather than to forego empirical work altogether.

The goal of this paper is to identify the determinants of awards in a comparative perspective. Rational choice theory is used to analyse what determines the demand for awards by utility maximising citizens wishing to achieve distinction, in addition to income. The supply of awards is undertaken by utility maximising principals, seeking to induce the actual and prospective recipients of awards (as agents) to act in their interests by using incentives. The relationship between the individuals bestowing and receiving awards is characterised by a tacit and far from perfect contract. The comparative static analysis allows us to derive a number of empirically testable propositions, based on income and relative price effects. It is, for instance, argued that the demand for awards is all the greater, the more homogeneous (the less fractionalized) a society is; the higher the income is; the greater the quality of the award is perceived to be; the less important the market is, and the more equal the market distribution produced between the persons. The supply of awards is proposed to be all the greater, the more reputation can be gained by handing them out; the more responsive potential recipients are; the more the donor is income constrained; the less effective self-binding mechanisms are; the shorter the donor's time horizon, the less recipients can renege on the implicit contract; and the less effective is monetary compensation. These general theoretical propositions, put in a more detailed form, are subjected to the analytic narrative analysis. It is shown that they are consistent with existing evidence, but that some puzzles remain.

present. But most treatises are restricted to particular orders, and refer on the whole to history (e.g. Galloway 2002).

${ }^{17}$ Frey and Buhofer (1988) use a similar approach to analyse the widely different ways in which prisoners of war have been treated in history. 
Overall, the analysis helps us to better understand the important role awards play in society. The economic analysis of awards was traditionally restricted to material, in most cases monetary rewards (see Jeffrey 2004), and has only recently been extended to intrinsic rewards (see e.g. Frey 1997). The present paper considers extrinsic, but non-material rewards.

Section II of the paper presents a short overview of the literature. The subsequent section derives the demand for awards driven by an individual's quest for distinction, and subjects the theoretical propositions obtained to an analytic narratives analysis. Section IV analyses the supply of awards in a principal agent setting with incomplete contracts. The theoretical propositions are again subjected to an empirical analysis. Section V concludes.

\section{Survey of the Literature}

The science of phaleristics (the Greek and Roman word for award) has produced a huge literature on specific awards, in particular on orders, decorations and medals. It is historically oriented and is mainly devoted to presenting the legal rules and regulations, and facts. Examples are Risk (1972) on the Most Honourable Order of the Bath, or Galloway (2002) on the Order of St Michael and St George. Most useful discussions (including some data) on the present state of orders, focusing on Britain, are provided in Phillips (2004) and the House of Commons (2004). Fewer works cover orders across several countries, for instance Klietmann (1984), Honig (1986), and Mericka and Marco (1990).

Awards have been discussed in a considerable literature in sociology. Examples are Bourdieu (1979), Elster (1983), Braudy (1986), Walzer (1983) or Baurmann (2002). With few exceptions, these works address awards and distinctions in general, but do not analyse particular types of awards. The literature fails to provide a theoretical analysis in a comparative perspective, and does not offer any empirically testable propositions, let alone testing the propositions empirically.

In economics, particular aspects of awards have been analysed in the context of the arts and culture $^{18}$. Ginsburgh and van Ours (2003) and Ginsburgh $(2003,2005)$ discuss Academy Awards (Oscars) in films, the Brooker Prize in literature, and the Eurovision Song Contest.

\footnotetext{
${ }^{18}$ See, in general the pathbreaking book by Baumol and Bowen (1966), or Peacock and Weir (1975), Blaug (1976), Throsby and Withers (1979), Frey and Pommerehne (1989), Towse (1993; 2003), Frey (2000). Wijnberg (2003) provides a short survey on awards in the arts.
} 
Glejser, and Heyndels (2003) analyse one of the most important piano competitions, the International Queen Elisabeth Prize. To my knowledge, no general study of awards has so far been undertaken in economics. An exception is Besley's (2005) unpublished "Notes on Honours", where he analyses why individuals show so much interest in awards that are, after all, often just pieces of ribbon.

Of course, many topics in economics have a bearing on the issue of awards. Particularly important are the economics of esteem (Brennan and Pettit (2004a; 2004b)), reputation (e.g. Akerlof (1976), Krebs, Milgrom and Roberts (1982), Besley and Kandori (1992), Tirole (1996)), identity (Akerlof and Kranton 2003), conventions (e.g. Young (1993)), status (e.g. Congleton (1989), Corneo and Jeanne (1997), Greene and Nelson (2002)), invaluable goods (Arrow 1997), superstars and positional goods (Scitovsky (1976), Rosen (1981), Frank (1985), Frank and Cook (1995)), signalling (Spence 1974), fame (Cowen 2000), relative utility, social comparisons, and reference groups (e.g. Fehr and Schmidt (1999), Miron (1995), Stutzer (2004)), the giving of gifts (e.g. Waldfogel (1993), Camerer (1988), Carmichal and MacLeod (1997), Prendergast and Stole (2001)), and the literature on incentives, in particular non-monetary incentives (e.g. Ward and Sloane (2000), Jeffrey (2004)) and symbolic incentives (e.g. Goodin (1980)) and intrinsic (e.g. Frey (1997), Bénabou and Tirole (2004)) incentives.

\section{The Demand for Awards}

Individuals have an innate desire to distinguish themselves from other individuals. People have a strong urge to be better than others. The quest for social distinction is taken to be a hard-wired trait of human nature ${ }^{19}$. The standard utility function, including the level of consumption $\mathrm{C}$, is amended by distinction $\mathrm{D}$ :

$$
\mathrm{U}=\mathrm{U}(\mathrm{D}, \mathrm{C})
$$

Both arguments produce utility, but at a decreasing marginal rate: $\mathrm{U}_{\mathrm{D}}>0, \mathrm{U}_{\mathrm{DD}}<0 ; \mathrm{U}_{\mathrm{C}}>0$, $\mathrm{U}_{\mathrm{CC}}<0$.

$\mathrm{C}$ is a constant proportion (c) of income $\mathrm{Y}$

\footnotetext{
${ }^{19}$ This assumption is in line with the socio-biological and evolutionary literature; see e.g. Henrich and Gil-White (2001).
} 
(2)

$$
\mathrm{C}=\mathrm{cY} .
$$

Distinction can be produced by awards A or by income

$$
\mathrm{D}=\mathrm{D}(\mathrm{A}, \mathrm{Y})
$$

Thus, people are able to gain social distinction by having an award, like an order, but also by having a higher income than other persons, as suggested in the economic literature on social comparisons and reference groups. An individual's relative position is enhanced both by receiving awards and having a higher income (see e.g. Stutzer (2004)). The possibility to produce distinction is in both cases subject to diminishing returns: $\mathrm{D}_{\mathrm{A}}>0, \mathrm{D}_{\mathrm{AA}}<0 ; \mathrm{D}_{\mathrm{Y}}>0$, $D_{Y Y}<0$. Awards can be gained by investing effort e into activities pleasing the persons handing out the awards. This may consist of productive activities but may also constitute directly unproductive rent-seeking activities

(4) $\quad \mathrm{A}=\mathrm{A}(\mathrm{e})$.

Effort devoted to gaining awards is subject to diminishing marginal returns: $A_{e}>0, A_{e e}<0$. Market income is produced by investing effort $\mathrm{k}$ :

(5) $\quad \mathrm{Y}=\mathrm{Y}(\mathrm{k})$,

which is also subject to diminishing marginal returns: $\mathrm{Y}_{\mathrm{k}}>0, \mathrm{Y}_{\mathrm{kk}}<0$.

For simplicity, total effort is normalized to one. The analysis focuses on the choice between devoting time to award-seeking activities or to market activities:

$$
\mathrm{e}+\mathrm{k}=1 \text {. }
$$

Individuals maximise their utility with respect to the (amount of) time devoted to award seeking. The optimal amount of effort $\mathrm{e}^{*}$ is implicitly given by

$$
\frac{\partial U}{\partial D} \cdot \frac{\partial D}{\partial A} \cdot \frac{d A}{d e}=\left[\frac{\partial U}{\partial D} \cdot \frac{\partial D}{\partial Y}+\frac{\partial U}{\partial C} \cdot \frac{\partial C}{\partial Y}\right] \frac{d Y}{d k}
$$

The left-hand side shows the benefits received by gaining distinction and therewith utility from awards; the right-hand side shows the marginal costs by reducing the (share of) time devoted to market activities $\mathrm{k}$ accordingly. It consists of the decrease in distinction due to a lower income and a direct decrease in consumption $\mathrm{C}$. 
In order to derive an explicit solution, the utility and production relationships are formulated as Cobb-Douglas functions.

(1a) $U=D^{\delta} C^{\varepsilon}$

(3a) $\quad D=A^{\alpha} Y^{\beta}$

(4a) $\quad A=e^{\mu}$

(5a) $\quad Y=k^{\rho}$

where all parameter values are positive. The parameters $P=\{\alpha, \beta, \delta, \varepsilon, \mu, \rho\}$ are exogenous to the demanders but subject to interventions (via the policy instruments $\mathrm{X}$ ) by the suppliers of awards (see section IV). The equilibrium condition (7) determines the demand for awards

(7a) $e^{*}=\frac{\mu \alpha \delta}{\mu \alpha \delta+\rho(\beta \delta+\varepsilon)}$

with $\frac{\partial e^{*}}{\partial \delta}>0, \frac{\partial e^{*}}{\partial \varepsilon}<0, \frac{\partial e^{*}}{\partial \alpha}>0, \frac{\partial e^{*}}{\partial \beta}<0, \frac{\partial e^{*}}{\partial \mu}>0, \frac{\partial e^{*}}{\partial \rho}<0$.

This formula allows us to derive testable hypotheses based on comparative statistics. They relate to (a) the productivity of work, (b) the production of distinction, and (c) the preference structure.

\section{a. Productivity of work}

Individuals devote all the more time and effort to seeking awards, the more productive this activity is compared to market work (in terms of eq. $7 \mathrm{a}, \mu$ is low compared to $\rho$ ).

Proposition 1. In countries in which rent-seeking activities are important in social and political life, individuals (cet. par.) invest considerable effort and time in award-winning activities, as their productivity $(\mu)$ is increased.

Rent-seeking societies (see Tullock (1967), Krueger (1974), Bhagwati (1982), and for surveys Tollison (1982) and Tollison and Congleton (1995)) are characterised by the dominance of bureaucratic, political and bargaining elements in decision-making. This applies to dictatorships and authoritarian countries, as well as to fossilised countries with strong interest groups (Olson 1982). Invariably, such countries subdue the market and compensate 
individuals for effort by handing out awards. As a result, individuals devote a considerable amount of effort to directly unproductive rent-seeking in order to achieve awards ${ }^{20}$.

\section{b. Production of distinction}

Individuals choose whether to gain distinction by receiving awards or by achieving a higher market income. The more distinction produced by awards relative to income ( $\alpha$ is large compared to $\beta$ ), the more effort devoted to activities designed to gain awards.

Proposition 2. The higher the quality of awards (the higher $\alpha$ ), the more awards are in demand.

The quality of an award is the higher, the more it is held in esteem by the individual's reference groups and the population at large. Such recognition is cet. par. the higher, the less other people receive the award, the more highly esteemed the former recipients are, and the more distinguished the award's tradition is.

The more objective and fair the distribution of awards is, the more they contribute to the recipient's distinction, and the greater is the demand for them. Conversely, if awards can be bought, i.e. if there is corruption, they contribute little or nothing to a recipient's distinction ( $\alpha$ is low) but they may still serve as a signal for the recipient's income and wealth.

In some societies, outside intervention may make it impossible for the market to produce distinction (low $\beta)$.

Proposition 3. The more the market is prevented from providing distinction, the more awards are in demand.

In socialist and planned economies, the market is to some extent blocked (see Walzer 1983). Market activity is subdued and unable to produce the differences in income which individuals seek to attain distinction.

The market sector can be supposed to be all the more important as a producer of distinction, the larger it is. When the market plays a minor role in a society/economy, the distinction gained through income may appear of little relevance to a population used to other forms of distinction.

\footnotetext{
${ }^{20}$ The choice of individuals to devote their efforts to productive vs. rent-seeking activities has been analysed in the context of entrepreneurship by Baumol (1990) and Murphy, Shleifer and Vishny (1991).
} 
Proposition 4. The more important the market sector of an economy is, the smaller the demand for awards handed out by the government or monarch.

The size of the market can be measured by the size of the corporate sector, and approximated by the capitalised value of traded shares. Alternatively, it can be measured by the absence of regulations and suppression of market activities. According to this definition, the classical market economies are the United States and Canada. The afore-mentioned lack of importance of orders bestowed by the government suggests that this proposition is consistent with empirical observations. However, within the corporate sector, awards seem to play a substantial role, especially in the United States. Such corporate awards are not inconsistent with the above proposition, which relates to awards handed out by political actors.

In contrast, in countries with relatively small or suppressed market sectors, awards are in greater demand. This was especially true in Britain before the Thatcher revolution. The market has since gained prominence. Correspondingly, proposition 5 predicts that the demand for (governmental) awards falls. In recent years, the British honours system has indeed come under attack. This has been reflected in two official reports (Phillips (2004), House of Commons (2004)) that suggest major reductions in the number of orders and types of orders granted by the government. The House of Commons Report (2004) makes the recommendation that no new appointments are made to the Order of the British Empire, the Order of the Bath and the Order of St Michael and St George, and that they are substituted by one single new order (Order of British Excellence). This would mean the end of the Sir/Dame title associated with some of these orders.

The income distribution produced by the market may in some societies (for traditional reasons) not contribute to distinction (low $\beta$ ).

The more equal the distribution of income and wealth is, the more individuals seek distinction in the form of awards. Individuals are unable to find social reputation by having a higher income than others (low $\beta$ ). They therefore turn to awards in order to distinguish themselves.

Proposition 5. The greater equality there is with respect to market income and wealth, the more awards are in demand.

The communist countries of the former Soviet empire strongly equalised the distribution of income and wealth. People more or less earned the same income, irrespective of their 
position $^{21}$ or work efforts. Individuals were therefore eager to establish social distinction by gaining awards. Communist countries had indeed an elaborate system of honours, the bestknown being the "Hero of Work", but there were hundreds of such awards for all kinds of activities and efforts. About one in every 1,000 Russians (men, women and children) received a state award (Phillips 2004: 56); probably a far higher amount than in most comparable countries.

Proposition 5 is also consistent with the observation that the Scandinavian countries, which put so much emphasis on equality of income, have not done away with orders and medals. All of them use state awards to honour people ${ }^{22}$.

The less distinction is produced outside the awards system, the more individuals are motivated to seek distinction in the form of awards (low $\beta$ compared to $\alpha$ ). When existing conditions contribute to clearly observable social distinctions, awards become less important.

Proposition 6. The more fractionalised or isolated the setting in which an individual lives, the lower is the demand for distinctions and for awards.

In a country with extensive fractionalisation ${ }^{23}$, i.e. where people are geographically separated into small groups, and where mobility is low, social distinction has to a large extent been established by history: each person is more or less aware of his or her position (e.g. son of the mayor). With a racially, culturally, linguistically and religiously diverse population, social distinctions are well established and there is little demand for further differentiation via awards. In contrast, if the population is more or less homogenous, individuals seek social distinction in the form of awards.

The effects of isolation and low mobility extend also to the social and political spheres. The less marked the socio-economic differences are (with respect to race, culture, language and religion), the greater is the demand for awards.

\footnotetext{
${ }^{21}$ This only holds for monetary income, but not for economic opportunities. Members of the Communist party, especially members of the Politbureau, had significant economic privileges, such as being able to get otherwise unavailable goods in special shops, datchas etc. But the ruling class (the Nomenclatura) made a great effort to maintain the illusion of economic equality.

${ }^{22}$ Sweden officially discontinued its honours system for nationals in 1975, but there are nevertheless a number of medals available, most importantly the King's Medal (with various grades, see the Appendix). The government also bestows a number of awards. In addition, Royal Academies and other Royal societies present medals (Phillips 2004: 57).

${ }^{23}$ This concept has been used to great advantage by Alesina and Ferrara (2000), and by Alesina et al (2003).
} 
Political centralisation imposes uniformity on the population of a country. In order to establish the sought-after social differentiation, people seek to distinguish themselves by whatever means possible, be it through income differences or through awards.

Proposition 6 can be empirically illustrated in the case of Switzerland (e.g. Steinberg 1996), a country that is strongly fractionalised in all three respects. Its geography is characterised by high mountains and deep valleys, as well as by many rivers and lakes. It has four native languages (German, French, Italian and Romanch), with virtually hundreds of dialects in common usage. Accordingly, culture also differs markedly over a small area. Switzerland has two major religions, Catholicism and Protestantism, the latter being divided into Calvinists and Zwinglians. With a population of only 7.5 million, Switzerland nevertheless has 26 cantons and more than 3,000 communes (all with substantial decision-making powers). It is one of the most federalist countries in existence. This heterogeneity is, according to the three propositions, consistent with the observation that no Swiss government hands out any orders or decorations, not even in the armed forces ${ }^{24}$ There are only a very small number of medals awarded by communal governments, mostly for cultural achievements.

Another country with considerable socio-economic and political diversity is the United States. Slavery and immigration have made it racially and linguistically heterogeneous, although English remains the single official language. The US is perhaps the most religiously diverse country in the whole world. The country is divided into 50 States and a large number of communes, all with considerable independence. Based on these three observations, we would expect the US to have few government awards. This definitely holds for the civil sector. The central government hands out only three (civilian) awards: The Congressional Gold Medal, created in 1776, and the Presidential Medal of Freedom (1945), and the Presidential Citizens Medal (1969).

Switzerland and the United States can be contrasted with France ${ }^{25}$, whose geography and population is far more homogenous. The various parts of the country, while historically very different from each other, have been homogenised by the last kings (Louis XIV and Louis $\mathrm{XV}$ ), revolutionaries (they opposed all fractionalisation) and the Napoleonic Empires. Most of the country's citizens are (at least nominally) Catholic, and all have to speak French.

\footnotetext{
${ }^{24}$ The Swiss Army is composed of more or less all male Swiss citizens, and there are only very few professional officers. The Army is therefore seen to be a reflection of the civilians.

${ }^{25}$ This applies to the 20th century. Recently, racial, cultural and religious and political distinctions have become more diverse.
} 
Politically, France is one of the most centralised nations in existence, the regions and communes possessing little decision-making power. According to these three propositions, France is expected to be a country with many awards handed out by the government. This is indeed the case. Compared to Great Britain, France is centralised to a much greater degree and produces "four times as many awards as Britain in any one year" (House of Commons 2004: 2). The well-known "légion d'honneur" has been awarded to 4,000 persons since 1967 (Phillips 2004: Annex 2) ${ }^{26}$. In addition, there are several other orders and medals bestowed by the government, such as the National Order of Merit, or the "palmes academiques".

Italy is another country homogenised by the political unification process (Risorgimento). Until recently, the central government in Rome dominated politics, leaving little power in the administrative regions. Therefore, we would expect Italy to have a well-developed system of orders and decorations. Again, this is the case. Orders play a significant role in Italy. The titles "Cavaliere" and "Commendatore" are commonly used. The Order of Merit of Work has no fewer than 850,000 living members (House of Commons 2004: 2).

Awards as such are not taxed (what could be taxed are the possible income transfers accompanying them). The tax burden of a person awarded, for instance, the title "manager of the year" or a knighthood, does not increase. In contrast, if social distinction is achieved by income, the respective income is subject to taxation (in terms of eq. $7 \mathrm{a}, \rho$ is low compared to $\mu)$. Due to this relative price effect, awards are a more attractive way of achieving social distinction than is higher income. This effect is the stronger, the higher the tax progression is.

Proposition 7. The higher the marginal tax rates on income, the larger the demand for awards.

Individuals in Britain before Maggie Thatcher's time, as well as individuals in Scandinavian and numerous other European countries, were burdened by high marginal taxes. In the United States and, by way of exception among European countries, in Switzerland, individuals' tax burden was lower. This helps to explain why, in the former countries, awards played a greater role in social life than in the US and in Switzerland. Since the end of the last century, the situation in some of the European countries has changed and the top tax rates on income and

\footnotetext{
${ }^{26}$ Another source (the wikipedia article on the legion d'honneur) indicates a much higher number. The award is reported to have 113,780 bearers.
} 
wealth have been lowered, which holds especially for Britain ${ }^{27}$. This means that, in relative terms, lower income persons are now expected to exert a greater demand for awards than do higher income earners. This can indeed be observed. More awards are now bestowed on persons with lower income rather than with higher income. The amount of state honours accorded to groups with below average income has risen markedly. From 1965 to 2004, the percentage of orders ${ }^{28}$ granted to women has increased from about 16 to 35 percent, and the percentage of orders going to black and minority ethnic groups has increased from 2 to 6 percent (Phillips 2004: 73-4).

\section{c. Preference structure}

The more highly a society esteems awards compared to material success (high $\alpha$ compared to $\beta)$, the more effort individuals devote to gaining awards.

Proposition 8. The stronger the market ideology, i.e. the more socially recognised is the distinction produced by the market, the smaller the demand for awards.

Capitalist societies tend to measure success according to income. A pertinent example is the United States where, in general, state awards are considered less important than private wealth. This is consistent with the observation that, in comparison to other countries, the US has few (only three) state awards.

At the beginning of the Federal Republic of Germany, market ideology was considered a central value. Accordingly, persons who were successful in the market had a high standing and did not need to bolster their reputation by seeking awards. This may help to explain why there is only one order, the "Bundesverdienstorden" (Order of Merit). In recent decades, the market ideology has waned which, according to proposition $4 \mathrm{~b}$, should have been accompanied by an increase in the demand for orders. However, the number of such awards has in fact dropped from 5,257 in 1991 to 3,316 in 2000 (Phillips 2004: Annex 2). Yet the former German president Rau recently stated that a new additional goal of awarding the Bundesverdienstkreuz is to direct public attention to achievements contributing to improved job opportunities and the creation of new jobs. Similarly, outstanding entrepreneurial and

\footnotetext{
${ }^{27}$ More than 20 years ago, Maggie Thatcher and Ronald Reagan triggered a world-wide revolution by dramatically slashing marginal income tax rates. Top tax rates in developed nations - on average - are nearly 20 points lower today than they were in the 1970s (http://executivecaliber.ws/sys-tmpl/taxineurope/).

${ }^{28}$ Covering the Order of the Bath, the Order of St Michael and St George, the Order of the British Empire, the Companion of Honour, as well as Knights Bachelors.
} 
scientific achievements with an innovative character will be used as a criterion for selecting recipients of the honour in the future. Thus, the German Order of Merit will be used as a substitute for the kind of recognition formerly achieved by economic success (Corrosion People 2002). In Russia, the market has achieved considerable reputation, particularly in the faster growing areas of the country. At the same time, the excessive amount of awards during the Communist era seems to have subsided and the distinction acquired by market income has become more important.

Individuals are influenced in their evaluation of awards by the history of their society. In countries in which awards have existed for a long time and have played an important part in establishing the social hierarchy, individuals value awards more highly than in countries in which no such tradition exists ( $\alpha$ higher than $\beta$ ).

Proposition 9. In societies characterised by an aristocratic tradition, individuals exert a higher demand for awards than in societies characterised by republican traditions.

Examples are the United Kingdom, Belgium and The Netherlands, where orders and decorations are held in high esteem in society and are used extensively. In Austria, despite having introduced a republic after WWI, the government still confers titles, such as "Hofrat" (i.e. Court Advisor), which explicitly refers to the monarchy. Accordingly, individuals in these countries make a huge effort to achieve the distinction of an award. In contrast, in Switzerland (which never had a monarchy), or in the United States (which claimed its independence from Britain and therefore chose democracy in preference to a monarchy), state awards, like orders and titles, are used sparingly (as in the US) or not at all (as in Switzerland).

In a society with a more marked inequality aversion with regard to the inequality of income or wealth, rather than with regard to the inequality of awards ( $\beta$ is small compared to $\alpha$ ), individuals turn to awards in order to acquire a reputation for themselves.

Proposition 10. The more economic inequality violates a socio-political norm, the larger are an individual's demand for awards.

The inequality aversion existing in a particular society can be captured by appropriate surveys. It can also be indirectly measured by an outcome, namely the amount of left-wing parties in parliament or government. According to this statistic, the Scandinavian countries 
have a higher inequality aversion with regard to income differences ${ }^{29}$ and are therefore expected to have a high demand for awards. This is consistent with the substantial importance of awards in these societies.

In contrast, in the United States, there is little aversion against economic inequality, the major reason being that Americans assume that there is a high upward mobility in their country. Research on happiness (Alesina et al. 2004) has indeed shown that the well-being of Americans is not diminished by rising income inequality, because they think it is likely that they can profit from income inequality by getting into a high-income class in the future. According to proposition 15, there should be a low demand for (civilian) awards compared to Europe, where people suffer a loss of well-being from income inequality.

In rich countries, the marginal utility of consumption is low $\left(\mathrm{U}_{\mathrm{C}}>0, \mathrm{U}_{\mathrm{CC}}<0\right)$ compared to poorer countries. The same applies to individuals with high income; they seek utility by gaining distinction through awards.

Proposition 11. The richer a country or particular individual, the larger is the demand for awards.

High income is consistent with an abundant use of awards, examples of which are the rich countries Denmark, Holland and Belgium. The Danish Orders of the Elephant and of the Danneborg belong to the oldest and still most prestigious awards in existence (they were created in 1462, and in 1219, respectively), and the Dutch and Belgian governments and monarchs hand out orders and titles liberally (as shown in the Appendix).

Higher income does not prohibit the introduction of orders. Canada, for example, has for lengthy periods of time (1917-32, 1935-40, 1946-67) foregone honours, but since Canadian income has risen, the central government has introduced three orders, the Order of Canada, Meritorious Service Decorations and the Caring Canadian Award. Similarly, China did not use to have a national honour system as such, but now plans to introduce a more comprehensive system (Phillips 2004, Annex 2).

Rich individuals derive little additional benefit from higher income, a feature empirically documented by the economic research on happiness (see e.g. Layard (2005), Diener and

\footnotetext{
${ }^{29}$ In Sweden, for example, the Social Democrats have been dominating Swedish politics for almost half a century. Their dominance has now weakened somewhat but they are still the single largest party. They vehemently reject differences leading to social ranking and social divisions in power and influence.
} 
Seligman (2004), Frey and Stutzer (2002a), (2002b), Easterlin (1974)). As a result, individuals seek further distinction through awards that cannot be bought on the market. Cultural institutions, such as opera houses and museums, took advantage of this wish by giving their sponsors titles that sound good (such as "Benefactor"). The Secretary General of the United Nations does the same by honouring rich and important people with a "Special Ambassador" title and by bestowing a substantial number of awards (see the Appendix). The American president, once elected, also often appoints people to ambassadors who contributed large sums of money to his campaign and are rich, though not necessarily well versed in diplomacy. These are indications that (very) high-income individuals value awards greatly.

\section{SUPPLY}

The institution (or person) bestowing an award can be taken to be a principal who maximises his utility by inducing the agents, as the recipients of the awards, to behave in his interests. The principal-agent relationship between the donor and recipient of awards involves a tacit and incomplete contract. The terms of the award contract are not precisely specified, and are often deliberately left vague. The tacit contract between the donor and recipient of an award differs significantly from a trade contract on a market in which an agent is promised payment for a well-defined performance (for instance for delivering a good). If the principal accepts the performance as satisfactory, the agent receives the payment and is then free of any further obligation. In particular, such an exchange does not establish any special bond; the agent is perfectly free to offer the goods to any other prospective buyer. An employment contract also differs from an award contract. The performance is often explicitly and precisely specified, and the monetary compensation is again paid after the service has been rendered. Once the employment contract is ended, the employer is free to offer the services elsewhere. But such contracts apply mainly to simple tasks. Employment contracts for more qualified tasks share some of the features of award contracts. The tasks to be performed are incompletely specified, and can be only partially monitored and enforced by the principal. In that case, the agent is expected to exhibit loyalty towards the principal. But in contrast to award contracts, once the employment relationship has ended, no further loyalty is owed ${ }^{30}$. Managers can therefore be observed to freely switch from one firm to another, or soccer players (with the approval of

\footnotetext{
${ }^{30}$ An exception is when the employee has acquired firm-specific secrets.
} 
their present clubs) to transfer to an archrival. While a person may receive awards from other donors (e.g. an order from a monarch of another country) this in no way ends the obligation to maintain loyalty to the previous donor.

The principal's utility $\mathrm{W}$ is the higher, the more support $\mathrm{S}$ he receives from the agent, and the lower the cost $\mathrm{K}$ of providing the awards:

$$
\mathrm{W}=\mathrm{W}(\mathrm{S}, \mathrm{K})
$$

The utility function is characterised by diminishing marginal returns: $\mathrm{W}_{\mathrm{S}}>0, \mathrm{~W}_{\mathrm{SS}}<0 ; \mathrm{W}_{\mathrm{K}}>$ $0, \mathrm{~W}_{\mathrm{KK}}<0$.

The support received by the principal due to handing out awards is determined by the efforts $\mathrm{e}^{*}$ given by equations (7) and (7a)

(9) $\mathrm{S}=\mathrm{S}\left(\mathrm{e}^{*}\right)$, with $\mathrm{S}_{\mathrm{e}}>0, \mathrm{~S}_{\mathrm{ee}}<0$.

The amount of effort provided by the potential recipients of awards can be influenced by various policies

(10) $\quad \mathrm{e}^{*}=\mathrm{e}(\mathrm{X})$

These policies are denoted in general by $X$. They change the value of the parameters $P=\{\alpha, \beta, \delta, \varepsilon, \mu, \rho\}$ which are exogenous to the recipients of awards.

As there are many different policies which the principal can use to influence the potential recipients' behaviour, the effect of $\mathrm{X}$ on $\mathrm{e}^{*}$ cannot be determined in general, but depends on the specific policy undertaken.

The policies undertaken are subject to increasing marginal costs:

(11) $\mathrm{K}=\mathrm{K}(\mathrm{X})$,

with $\mathrm{K}_{\mathrm{X}}>0, \mathrm{~K}_{\mathrm{XX}}>0$.

The optimal supply of policy intervention by the principal $\mathrm{X}$ is defined by:

$$
\frac{\partial W}{\partial S} \cdot \frac{\partial S}{\partial e^{*}} \cdot \frac{\partial e^{*}}{\partial P} \cdot \frac{d P}{d X}=-\frac{\partial W}{\partial K} \cdot \frac{d K}{d X} .
$$

This formula allows us to formulate testable hypotheses on the determinants of the award giver's policies. Subsection (a) discusses policies influencing the effectiveness of awards 
$(\partial D / \partial A)$; subsection (b) considers policies influencing the effectiveness of the award-winning efforts; (c) deals with how award-winning efforts affect the support received by the principal; (d) analyses how support affects the award giver's utility; and (e) shows the effects of changes in the costs of providing the policies on the award giver's utility.

\section{a. Raising the capacity of awards to provide distinction}

The principal can profitably increase the effect an award has on achieving distinction to the recipients in various ways. In all cases, $\mathrm{X}$ raises $\alpha$ and thus $\partial D / \partial A$, which, according to eq. (11), increases the recipient's marginal benefit of obtaining an award.

The principal must ensure that the sheer number of awards is kept within bounds. The quality of an award depends on its rarity. This has been clearly expressed by Winston Churchill in a speech in the House of Commons, 22 August 1944: “... a distinction is something which everybody does not possess. If all have it, it is of less value" (Cabinet Office 2004:1). The award-giving institution therefore has an interest in restricting the number of awards and guarding against a decline in quality due to an oversupply. For this reason, the institution must be able to credibly bind itself. Institutions with a long history and high stability find it easier to establish and observe such self-constraints.

Proposition 12. The more effective the self-imposed institutional restrictions to control the number of awards given, the more effective awards are as incentive instruments.

The British monarchy has been successful in stringent self-imposed restrictions on the number of titles conferred in some of the orders. One of the reasons the Most Noble Order of the Garter and the Most Ancient and Noble Order of the Thistle (which is bestowed personally by the Sovereign) are held in such high esteem is that the number of Knights/Ladies is restricted to 25 and 16, respectively (Phillips 2004). The highest British order, the Victorian Cross, has only been bestowed 1,354 times since 1856. New Zealand also restricts the number of members in the Order of New Zealand, the New Zealand Order of Merit and the Queen's Service Order to 20, 30 and 140 per year, respectively.

In contrast, the Italian Republic, with a similar population to the UK, hands out state awards very liberally. The Order of Work has no fewer than 850,000 living members, and each year 
20,000 more are added. The French Republic has maximum limits on the 5 ranks of her légion d'honneur, but in actual fact greatly exceeds the limits ${ }^{31}$.

These observations are consistent with the above proposition. The British monarchy goes way back in history and is very stable, whereas the Italian and French governments have been among the most unstable governments in Europe. Consistent with our analysis, orders and titles in Britain have been able to retain much of their esteem (see Phillips 2004), while in Italy and France this is clearly less so.

The perennial problem of reducing the effectiveness of awards, or aggrandising awards, can be counter-balanced by creating new awards, or new classes of awards. Due to the reactions of the prospective recipients, there are of course limits to this possibility.

Proposition 13. The more institutional flexibility the principal has to differentiate between awards, the better the quality can be maintained when the overall number of awards increases.

Most institutions have considerable flexibility when it comes to creating new awards. Most government leaders, who send their troops to war, invent a corresponding decoration in order to please the soldiers and officers involved. But democratic governments have at least some restrictions because they have to observe certain rules and conventions. Dictators are, in this respect, almost totally unconstrained. As a consequence, one can observe that dictators create an abundance of orders, medals and decorations. This not only applies to some autocratic rulers in Africa, but also in Europe. For example, in 1938, Hitler reinstituted the Iron Cross and, over the course of the War, more and more classes were added to the traditional four classes. There was an "Eisernes Kreuz" Second and First Class, the Knight's Cross, and the Knights Cross with Oak Leaves, with Oak Leaves and Swords, with Diamonds, with Golden Diamonds and A Grand Cross (awarded to Reichsmarschall Goering). The Japanese Emperors, who in this respect seem rather unconstrained, have exhibited considerable inventiveness by creating many classes amongst their orders. Examples are the Order of the Rising Sun with nine classes, and the Order of the Precious Crown and the Order of the Sacred Treasure with eight classes each (Phillips 2004: 53).

Private institutions also have considerable leeway to create new awards. Examples are the honours awarded by the media to managers. At the beginning, a "Manager of the Year" was

\footnotetext{
${ }^{31}$ For instance, the number of Commanders is restricted to 1250 , but there are actually 3626; the respective numbers for Officers are 10,000 and 22,401 (http://de.wikipedia.org/wiki/Ehrenlegion).
} 
appointed. Today, there is a "Manager of the Month", and this award is subdivided according to economic sectors. The same happened with Beauty Queens, such as "Miss World", "Miss Universe" etc. In each of these cases, the quality of the award suffers to some extent, but certainly less than if there wasn't any differentiation at all.

The quality of an award suffers when the donor bestows it, but it is not accepted. As a result, the award becomes less effective as an incentive instrument. The damage to the award's reputation is the greater, the more widely known the refusal is ${ }^{32}$. The damage to the donor's and award's reputation is greater still if recipients turn out to be unworthy.

Proposition 14. The quality of an award is the better maintained, the lower the probability that the award is publicly refused.

Institutions handing out rewards can be seen to make great efforts to ensure that the persons chosen will accept the awards. This is demonstrated by the British system of bestowing orders. After having been chosen by carefully selected committees, and after having been scrutinised by the Ceremonial Secretariat of the Cabinet Office, the prospective recipients are asked whether they will accept the honour. Only if they formally agree is the list put forward to The Queen and then officially published in the London Gazette (House of Commons 2004). 98 percent of those offered awards accept them, and the majority of the 2 percent who decline do so for private reasons (Phillips 2004: 5). This procedure ensures that a refusal is not made public, except when a leak occurs. In Britain, the orders and medals enjoy high prestige and respect and receive solid public support (House of Commons 2004:3). This is consistent with the care that is taken to avoid refusals (Phillips 2004: 5).

The Nobel Prize Committee is more restricted in this respect. As the conferral is kept secret, the prospective recipients cannot be asked whether they will accept. The Committee must make its own inquiries, and carefully deliberate the risk of refusal. Nevertheless, it sometimes happens, the best known example being Jean Paul Sartre's refusal of the Nobel Prize in Literature. This particular Nobel Prize is indeed more controversial, and is generally less valued, than the Nobel Prizes in the Sciences where few, if any, refusals are known. These observations are consistent with proposition 14.

\footnotetext{
${ }^{32}$ This happened in Britain in December 2003 when a confidential document, containing the names of over 300 such persons, was leaked to the Sunday Times. Some well-known persons on the list were Francis Bacon, Isaiah Berlin, David Bowie, Roald Dahl, Bernie Ecclestone, Graham Greene, Alfred Hitchcock, David Hockney, Aldous Huxley, John Le Carré, John Lennon, Doris Lessing, Harold Pinter, J.B. Priestley, Vanessa Redgrave, Keith Richards, Evelyn Waugh.
} 
Proposition 15. The award's quality and usefulness as an incentive device is higher, the better the principal can ensure that the recipients prove to be worthy of it.

The Catholic Church has an elaborate system to ensure that only those persons are beatified and sanctified who deserve it according to their carefully formulated standards. It has used an ingenuous institution for that purpose, the advocatus diaboli. This person is officially given the task of finding potentially harmful aspects in the life of people proposed as beati or sancti. Accordingly, one rightly speaks of a "process", in which both the positive and the negative sides are represented. The Church is well aware that its reputation would suffer badly if a (recently appointed) saint would turn out to be unworthy. But, due to its long-standing experience and history, it has managed admirably and saints are still venerated by a huge number of church-members and non-church members alike. Mother Teresa being canonised is a good example ${ }^{33}$.

The Nobel Prize Committee also makes huge efforts to ensure that the recipient of a Prize deserves it. It resorts to extensive consultations within the scientific community. It even checks out whether a scholar can be expected to behave in the appropriate way at the award ceremony, where the Swedish King bestows the Prize $e^{34}$.

A relatively safe way to avoid giving honours to unworthy persons is to give them only after they have proved to be loyal to the donor. For that reason it can be observed that orders where the issue of loyalty is most important - are predominantly given at an advanced age (for Britain, see the extensive documentation in the House of Commons (2004), Phillips (2004)). Where loyalty is of lesser importance, and present work effort matters more, awards are given to younger people. Examples are the American John Bates Clark Medal or the German Leibnizpreis. These observations are consistent with proposition 16.

Giving awards not only has a positive incentive effect on the persons receiving or hoping to receive them, but may also have a negative external effect on the persons who are disappointed or angry at not having received them. This aspect was clearly seen by Winston Churchill in a House of Commons speech (22 August 1944): “A medal glitters, but it also casts a shadow. The task of drawing up regulations for such awards is one which does not

\footnotetext{
${ }^{33}$ Pope John Paul II recently changed the rules. There is no longer an advocatus diaboli, but the task is given to a commission. This can be expected to greatly affect the procedure, and may well harm the Church's reputation by leading to more errors.

${ }^{34}$ A well-known documented case refers to John Nash (Nasar 1998).
} 
admit of a perfect solution. It is not possible to satisfy everybody without running the risk of satisfying nobody. All that is possible is to give the greatest satisfaction to the greatest number and to hurt the feelings of the fewest".

The more an award is conceived as a pure positional good (Frank (1985), Frank and Cook (1995), de Botton (2004), Marmot (2004)), the higher is the utility to the recipient but the more strongly it is counterbalanced by the utility loss of those not receiving it. In the aggregate, the incentive effect may even be counterproductive.

Proposition 16 The more an award is seen as pure positional good, the less productive it is in the aggregate as incentive instrument.

Award givers are aware of this effect and react to it. One possibility to mitigate the negative external effects on non-recipients is to introduce marginal changes in the system. When people have the possibility to slowly climb up a social ladder of classes for an award, or if the recipient must have a minimum age, outsiders are less inclined to perceive the award in terms of a positional good and suffer a smaller negative external effect. The Order of Merit of the Italian Republic does this by requiring a minimum age of 35 years and by not allowing people to jump grades; recipients must work their way up from Cavaliere, Ufficiale, Commendatore, Grande Ufficiale, Cavaliere di Gran Croce to Cavaliere di Gran Croce decorato di Gran Cordone.

There is another external effect award givers have to take into account. The recipients themselves may underperform after getting an award due to a "distraction" and "extraction" effect. An empirical study (Malmendier and Tate 2005) of US CEOs with "superstar" status, i.e. those who were appointed "Best Managers" by Business Week, indicates that there is a decline in performance following the receipt of the CEO award. Stock market performance and accounting profits of the corporations of the respective managers tend to fall. One reason is that the CEOs start to write books and sit on more boards of other firms. Another is that they extract much higher rents from their company and more strongly manage earnings.

\section{b. Raising the effectiveness of award-seeking activities}

The principal handing out awards must ensure that the prospective recipients are not demotivated when it comes to other pursuits, such as gaining income by market activities. Rather, they should feel that their effort to gain awards is duly taken into account. This means 
that the intervention $X$ raises $\mu$ (compared to $\rho$, or, more generally, $d A / d e$ compared to $\mathrm{dY} / \mathrm{dk})$, which in turn raises $\mathrm{e}^{*}$ since $d e^{*} / d \mu>0$.

Recent research on incentive systems and corporate governance (see the surveys by Daily, Dalton and Canella (2003), Bolton, Becht, and Roëll (2002), Prendergast (1999), Gibbons (1998)) suggests that monetary compensation does not always work well (see e.g. Bénabou and Tirole (2002), Frey and Osterloh (2001), Frey (1997)) $)^{35}$. This holds, in particular, when the task to be performed is difficult or impossible to specify ex ante, and to monitor ex post. In that case, it is hard to make a monetary payment considered fair by the recipients. "Soft" incentives (e.g. Holmstrom and Milgrom (1991),(1994)), which endeavour to take a broader view of the agent's efforts, are then more useful. Awards are well suited to that purpose. With a few exceptions in the military branch ${ }^{36}$, orders, decorations and prizes are given to honour more general efforts.

Proposition 17. The more difficult it is to formulate specific contracts ex ante, and to monitor ex post, the more efficiently awards function as incentives compared to monetary compensation.

According to Nobel's testament, his Prize should be given to the scientists who made the most important contribution to science in the previous year. The fact that the Nobel Prize is, in the overwhelming majority of cases, given instead based on a scholar's overall life performance, suggests that prizes serve that purpose more efficiently. On the other hand, one rarely observes a person being given a sum of money for his or her life achievement. If it were done, the question would immediately arise why the sum is not higher or lower. An evaluation in dollars and cents of what one has achieved, and how one has performed in life, is difficult, to say the least, and many would consider it offensive to have their life evaluated in these terms. The same question also arises with respect to awards, but it is less harmful exactly because the value of awards is purposely left vague. But precisely this property helps awards to efficiently compensate people for outstanding achievements.

There are parts of society where specific tasks are difficult, or impossible, to define ex ante, and to monitor ex post, and where an overall evaluation of effort is more efficient. Providing

\footnotetext{
${ }^{35}$ Extensive empirical laboratory and field evidence is collected in Frey and Jegen (2001).

${ }^{36}$ Some orders, such as the Victoria Cross, are given for specific acts of valour but most military decorations are not. The United States, by 1969, had given awards of valour, such as the Purple Heart, to 56 generals who did service in Vietnam, though only one general died from enemy fire at that time (Cowen 2000: 93).
} 
suitable data are available in the future, the importance of awards can be evaluated by looking at the lower monetary compensation in sectors and occupations with more awards compared to those with fewer awards (compensating variation).

Decorations are both extremely important and abundant in the military ${ }^{37}$, because exactly what tasks have to be performed, especially in combat, are largely unpredictable and cannot be contracted ex ante. The United States, for instance, knows only three civilian state $\operatorname{awards}^{38}$, but has about 170 military decorations (of which over 60 are currently in use), such as the Medal of Honor, the Distinguished Service Cross, the Distinguished Service Medal, Silver and Bronze Star, the Legion of Merit, Distinguished Flying Cross, Soldier's Medal, Meritorious Service Medal, Air Medal, Army Commendation, Purple Heart (Robertson 2005).

In the public sector, more awards are supplied because it is more difficult to assess the exante contract than in the market sector. The report of the House of Commons (2004: 3) refers to "the special generosity to state servants stemming from the relative modesty of public sector salaries when compared to the private sector". In recent years, salary levels have improved substantially, and at the same time "the long term trend was clearly away from the state sector". Yet, civil servants still receive "favourable treatment" (House of Commons 2004: 3-4). Fifty years ago, roughly 40 percent of all British state awards went to public servants, while today's percentage is below 14 percent.

Monetary compensation has been shown to crowd-out intrinsic motivation under specific circumstances, i.e. when the agents are perceived to be controlling (e.g Frey (1997), Osterloh and Frey (2000), Gneezy and Rustichini (2000a),(2000b), Bénabou and Tirole (2004)). This motivation crowding effect may overcompensate the relative price effect of the monetary incentive. This perverse effect of monetary compensation is the greater, the more important intrinsic motivation is for a task or sector. When an award is received, most persons take it as a gesture of support rather than of control, and it is therefore likely to have a positive, rather than a negative, effect on performance.

Proposition 18. In sectors and activities where intrinsic motivation is important, and is likely to be crowded-out by monetary compensation, awards are relatively more efficient.

\footnotetext{
${ }^{37}$ The fact that the Swiss army is the only exception can be attributed to the fact that it is almost only composed of conscripted citizens, and has not been involved in war for two hundred years.

${ }^{38}$ But there are several civilian awards, such as the "Arms Control and Disarmament Agency: Superior Honor Award" or the "Defence Contract Audit Agency Distinguished Service Award", as well as hundreds of other awards handed out by US States (Robertson 2005).
} 
Intrinsic motivation is of particular importance in the volunteering and humanitarian sectors, academia, the arts, the military, and parts of the public services (Frey 1997). The Appendix reveals that awards do indeed play a major role as an incentive instrument in these sectors.

\section{c. Raising the award-giver's utility from support}

An award giving institution can raise both the quality of its awards and its own recognition by conferring them on individuals who already have a high reputation. The transfer of the recipient's reputation to the giver raises the latter's level of general support. Due to the high media attention given today to a particular individual, the esteem of the award-granting institution is linked even more closely than before to one of the recipients. If the institution is able to induce famous persons, or celebrities, to accept one of their awards, their own utility is increased. This policy is of greater importance to institutions of low, rather than high, renown (since $\mathrm{W}_{\mathrm{S}}>0$, and $\mathrm{W}_{\mathrm{SS}}<0$ ).

Proposition 19. The less well-known an institution is, and the less esteem it is held in, the stronger is its incentive to gain reputation by handing out awards to celebrities.

Many organisations give famous sportspersons awards in the hope that they will attend the award-giving ceremony and therewith raise their prominence. Examples are the dominant formula 1 pilot Michael Schumacher, who has repeatedly been appointed "German Sportsman of the Year", or the present top-ranked tennis player, Roger Federer, who was twice appointed "Swiss Sportsman of the Year". While both accepted these honours, neither attended the actual ceremony. This reflects the fact that the award handed out is, in this case, of little value to the recipients, but rather to the award giving institution. But even governments and monarchies, which seem to be well established, try to gain added recognition (and, in the case of the government, votes) by bestowing orders and titles on famous persons. A case in point is the UK government and the British Queen who awarded an MBE to the Beatles, and most recently to a celebrity footballer, David Beckham ${ }^{39}$. Scholars who achieve fame by getting the Nobel Prize are knighted almost as a matter of course (in economics, for instance Hicks and Mirrlees $\left.^{40}\right)$.

A principal can also raise the utility gained from handing out awards by targeting them at individuals who are expected to respond, and to benefit the principal to a large extent.

\footnotetext{
${ }^{39}$ Other football heroes have been knighted, for instance Sir Stanley (Matthews).

${ }^{40}$ Another Nobel Prize winner, James Meade, refused this award on principle.
} 
Individuals in a pivotal position meet this criterion more than individuals who support the principal anyway, or who will never support him.

\section{d. Lower costs for the principal's policy}

A principal finds conferring awards the more suitable as an incentive instrument, the cheaper are the marginal costs of doing so (low $\left.\mathrm{K}^{\prime}(\mathrm{X})\right)$.

Institutions short of income have to turn to awards in order to provide incentives to the agents. Awards are extremely cheap in monetary terms. Sometimes they just consist of a piece of ribbon. In many cases, the recipients must buy the insignia of the order they are bestowed with. The only material cost involved is the ceremony in which the award is given. But again, these costs are in general quite low.

Proposition 20. The more an institution is restrained by a lack of income, the more it turns to awards to provide incentives.

The role of the income constraint on the supply of awards applies in particular to three institutions. Monarchies were strongly income restrained in the past, and today often have no independent source of income. They therefore tend to resort more to awards than do republics. The more income-constrained dictatorships in poor countries are, the more they use awards as incentive instruments. Not-for-profit firms are often very income constrained and therefore resort more frequently to awards than for profit firms.

The shorter the time horizon of the principals, the more they rely on awards, because the costs, in the form of award inflation, will only occur in the future.

Proposition 21. The lower the probability of continuing in power (in a democracy, the lower the re-election probability), the larger the number of awards supplied.

Before his resignation in 1976, the British Prime Minister Harold Wilson did great harm to the honours system by handing out far too many awards to Labour supporters (which was heavily criticised, see De-la-Noy (1985: 141)). When a regime fears for its survival, the time horizon is short and there is a great incentive to try to forestall this fate by using awards as incentives to supporters. Examples are the German Iron Cross, established in 1813, and highly esteemed up until the $20^{\text {th }}$ century. But it lost much of its lustre when it was given out to 5,400,000 soldiers in WWI, in which 13.2 million German soldiers were engaged, i.e. on 
average, 40 percent of all soldiers received one. As some soldiers received Iron Crosses of several classes, historians estimate that about 20 percent of the German soldiers were decorated in this way. Similarly, in WWII, 5,000,000 Iron Crosses were awarded by the Wehrmacht (Kellerhoff 2004). In both Wars, the Germans were on the losing side. The war leaders were, quite early on, aware of the fact that their chance of winning the war was small and diminishing ${ }^{41}$.

The same policy can be observed when the principal has a short-term time horizon due to bad health. Pope John Paul II, who had been in bad health for a number of years, and whose imminent death was often an issue, greatly increased the number of canonisations. $\mathrm{He}$ beatified and sanctified many more people than all the other popes of this century combined (Cowen 2000:94). Over the 26 years of his pontificate (1978-2005), John Paul II recognized 488 saints and beatified 1,338 persons, putting them on the path to sainthood. The press commented "... as with everything, inflation produces devaluation" (Hennerberger 2002).

When several institutions are able to hand out similar awards, a typical public good situation arises. A particular principal only takes into account his own costs of providing the awards, but not the costs of diminishing the quality of the awards falling upon all principals handing them out. But he is also burdened by the costs imposed from other principals handing out awards. Each prefers to act as a free-rider, in the sense that there is too low an incentive to keep the number of awards down and therewith keep their quality up. A principal faced with only a few, or no competing, award givers therefore has lower costs than one who has to act in a system with many award givers.

Proposition 22. The fewer other principals are able to independently supply similar awards, the better awards serve as incentive instruments.

The hundreds of principalities existing in Germany before the foundation of the German Reich distributed a great number of orders. The same holds for Italy before the Resorgimento. The resulting inflation of orders reduced their value.

Military decorations are also handed out more liberally when there is no strong central command, but the various branches of the military are in competition with each other and can

\footnotetext{
${ }^{41}$ This statement is empirically supported by an analysis (Frey and Kucher 2000, 2001) of the change in value of government bonds during the course of WWII. The bond prices increased for the Allied powers, while they fell for the members of the Axis.
} 
to some extent act on their own. In tandem with this expansion of different types of awards, the number bestowed also increases greatly. This is particularly visible in the United States. In the Revolutionary War, there was essentially one Military Force under General Washington's command. The Purple Heart was only awarded three times. In contrast, during WWII in one battle alone, at Iwo Jima, there were 28,686 casualties (of which 6,821 died), and each one received a Purple Heart (Cowen 2000: 93). Today, the American forces are composed of the Army, the Navy and the Air Force, and more recently of the Marines and the Coast Guard, each one having its own command, with a good measure of independence. The highest award of the US military, the Medal of Honor, was originally issued to members of the US Army. In 1947, the US Air Force began issuing its own version of the Medal of Honor, followed later by the US Navy and the Marines. There is also a US Coast Guard version.

Proposition 22 is consistent with the explosion in the number of awards given by not-forprofit institutions and by private enterprises. A case in point are the awards given to people in sports. Each year, the BBC bestows the following awards: "Sports Personality of the Year Team”, "Overseas Personality", "Coach", "Lifetime Achievement", "Young Personality" and "Unsung Hero". It seems that each sports organisation appoints its own "sports man", "sports woman" and "sports team" of the year, and increasingly also of the decade or even century ${ }^{42}$.

Proposition 22 suggests that political decentralisation increases the supply of awards while proposition 6 suggests that political decentralisation lowers the demand for awards. It follows that the value (price) of awards is lower than in a centralised polity.

\section{Summary and Conclusion}

Awards form an important part of the incentive system in a society. They deviate systematically in many respects from extrinsic incentives in monetary or material form, as well as from intrinsic incentives. Awards constitute a type of non-material extrinsic reward extensively used in all spheres of society, including the economy.

The paper shows that, based on the assumption that individuals have a hard-wired desire for social distinction, the determinants of the demand for awards can be analysed. A number of

\footnotetext{
${ }^{42}$ The Swiss Ski Association, for example, recently elected a male and a female "Skier of the Century" (Pirmin Zurbriggen and Vreni Schneider won this prize).
} 
propositions are derived, which are consistent with how individuals seek awards. The demand for awards is the higher

- the lower economic productivity is;

- the more important rent-seeking activities are;

- the less important the market sector is;

- the more equal the distribution of market income and wealth is;

- the less fractionalised a country is with respect to geographical, socio-economic and political aspects;

- the higher the marginal tax rates on income are; and

- the richer the country and in particular individuals are.

The supply side has been analysed in the context of a principal-agent relationship between the donor and the recipient of awards involving a tacit and incomplete contract. The terms of the award contract are not precisely defined, and are often left vague. Awards turn out to be efficient instruments to elicit the work effort and support desired by the donor of awards.

The propositions are, on the whole, consistent with the way awards are handed out. Awards are proposed to be the more efficient incentive instruments

- the more effective self-imposed restrictions to control the number of awards are;

- the more the donor is able to differentiate between awards;

- the lower the probability is that an award is publicly refused;

- the less possible it is to formulate specific ex ante contracts, and to monitor them ex post;

- the more important intrinsic motivation is; and

- the fewer other principals are able to independently supply similar awards.

An institution bestows the more awards

- the more restrained it is by a lack of monetary income; and 
- the lower the probability of continuing in office.

The unavailability of reliable and consistent data on awards prohibits employing econometric techniques to test these propositions. An alternative technique, analytic narratives, is applied. It enables the integration of knowledge stemming from many different sources and being of different qualities, but it is far from ideal. Nevertheless, as long as no reasonable data on awards is available, it seems to be better to resort to this technique than to forego empirical work altogether. At least it provides interesting insights from which to proceed further. 


\section{References}

Akerlof, George A. (1976). The Economics of Caste and of the Rat Race and Other Woeful Tales. Quarterly Journal of Economics 90(4): 599-617.

Akerlof, George A. and Rachel E. Kranton (2003). Identity and the Economics of Organization. Working Paper, University of California, Berkeley.

Alesina, Alberto (2003). Fractionalization. Journal of Economic Growth 8(2): 155-194.

Alesina, Alberto, Rafael Di Tella and Robert MacCulloch (2004). Inequality and Happiness: Are Europeans and Americans Different? Journal of Public Economics 88(9-10): 2009-2042.

Alesina, Alberto and Eliana La Ferrara (2000). Participation in Heterogeneous Communities. Quarterly Journal of Economics 115(3): 847-904.

Arrow, Kenneth J. (1997). Invaluable Goods. Journal of Economic Literature 35(2): 757-765.

Bates, Robert Hinrichs, Avner Greif, Margaret Levi, Jean-Laurent Rosenthal and Barry R. Weingast (1998). Analytic Narratives. Princeton, N.J.: Princeton University Press.

Baumol, William J. (1990). Entrepreneurship: Productive, Unproductive, and Destructive. Journal of Political Economy 98(5): 893-921.

Baumol, William J. and William G. Bowen (1966). Performing Arts, the Economic Dilemma; a Study of Problems Common to Theater, Opera, Music, and Dance. New York: Twentieth Century Fund.

Baurmann, Michael C. (2002). The Market of Virtue: Morality and Commitment in a Liberal Society. The Hague: Kluwer Law International.

Bénabou, Roland and Jean Tirole (2002). Self-Confidence and Personal Motivation. Quarterly Journal of Economics 117(3): 871-915.

Bénabou, Roland and Jean Tirole (2004). Incentives and Prosocial Behavior. Princeton Economics Discussion Paper No. 230, Princeton University.

Besley, Timothy (2005). Notes on Honours. Mimeo, London School of Economics.

Besley, Timothy and Michihiro Kandori (1992). Reputation as a Public Good. mimeo, Princeton University.

Bhagwati, Jagdish N. (1982). Directly Unproductive, Profit-Seeking (Dup) Activities. Journal of Political Economy 90(5): 988-1002.

Blaug, Mark (1976). The Economics of the Arts. Boulder, Colo.: Westview Press.

Bolton, Patrick, Marco Becht and Alisa Roell (2002). Corporate Governance and Control. ECGI - Finance Working Paper No. 02/2002, European Corporate Governance Institute.

Bourdieu, Pierre (1979). La Distinction. Critique Sociale Du Jugement. Paris: Les editions de minuit.

Braudy, Leo (1986). The Frenzy of Renown : Fame \& Its History. New York: Oxford University Press.

Brennan, Geoffrey and Philip Pettit (2004a). The Economy of Esteem : an Essay on Civil and Political Society. Oxford ; New York: Oxford University Press.

Brennan, Geoffrey and Philip Pettit (2004b). Esteem, Identifiability and the Internet. Analyse und Kritik 26(1): 139-157.

Camerer, Colin (1988). Gifts as Economic Signals and Social Symbols. American Journal of Sociology (Suppl.) 94: 180-214.

Carmichael, H. Lorne and W. Bentley MacLeod (1997). Gift Giving and the Evolution of Cooperation. International Economic Review 38 3: 485-509.

Cash (2005). 20 January 2005: 10-11.

Congleton, Roger D. (1989). Efficient Status Seeking: Externalities, and the Evolution of Status Games. Journal of Economic Behavior and Organization 11(2): 175-90. 
Corneo, Giacomo and Olivier Jeanne (1997). Conspicuous Consumption, Snobbism and Conformism. Journal of Public Economics 66(1): 55-71.

Corrosion People (2002). Bundesverdienstkreuz Für Dirk G. Kronsbein Materials and Corrosion. Corrosion People (http://www3.interscience.wiley.com/cgibin/fulltext/94518295/PDFSTART) 53(6): 436.

Coupé, Tom (2005). An Analysis of the Best Paper Prizes of Economics Journals. Working Paper, Universitè Libre de Bruxelles.

Cowen, Tyler (2000). What Price Fame? Cambridge, Mass.: Harvard University Press.

Daily, Catherine M., Dan R. Dalton and Albert. A. Cannella (2003). Introduction to Special Topic Forum Corporate Governance: Decades of Dialogue and Data. Academy of Management Review 28(3): 371-382.

De-La-Noy, Michael (1985). The Honours System. New York: Allison \&Busby.

Diener, Ed and Martin E.P. Seligman (2004). Beyond Money: Toward an Economy of WellBeing. Psychological Science in the Public Interest 5(1): 1-31.

Easterlin, Richard A. (1974). Does Economic Growth Improve the Human Lot? In: Paul A. David and Melvin W. Reder (eds). Nations and Households in Economic Growth: Essays in Honor of Moses Abramovitz. New York: Academic Press, Inc.

Economist, The (2004). The Economist, July 14, 2004: 31.

Elster, Jon (1983). Sour Grapes: Studies in the Subversion of Rationality. Cambridge: Cambridge University Press.

Fehr, Ernst and Klaus M. Schmidt (1999). A Theory of Fairness, Competition, and Cooperation. Quarterly Journal of Economics 114(3): 817-868.

Frank, Robert H. (1985). Choosing the Right Pond : Human Behavior and the Quest for Status. New York ; Oxford [Oxfordshire]: Oxford University Press.

Frank, Robert H. and Philip J. Cook (1995). The Winner-Take-All Society : How More and More Americans Compete for Ever Fewer and Bigger Prizes, Encouraging Economic Waste, Income Inequality, and an Impoverished Cultural Life. New York: Free Press.

Frey, Bruno S. (1997). Not Just for the Money: An Economic Theory of Personal Motivation. Cheltenham, U.K.: Edward Elgar.

Frey, Bruno S. (2000). Arts and Economics: Analysis and Cultural Policy. x, 240.

Frey, Bruno S. and Heinz Buhofer (1988). Prisoners and Property-Rights. Journal of Law \& Economics 31(1): 19-46.

Frey, Bruno S. and Reto Jegen (2001). Motivation Crowding Theory. Journal of Economic Surveys 15(5): 589 - 611.

Frey, Bruno S. and Felix Oberholzer-Gee (1997). The Cost of Price Incentives: An Empirical Analysis of Motivation Crowding-Out. American Economic Review 87(4): 746-755.

Frey, Bruno S., Margit Osterloh and Jetta Frost (2001). Managing Motivation, Organization and Governance. Journal of Management and Governance 5(3-4): 231-239.

Frey, Bruno S. and Werner W. Pommerehne (1989). Muses and Markets : Explorations in the Economics of the Arts. Cambridge, Mass., USA: B. Blackwell.

Frey, Bruno S. and Alois Stutzer (2002a). Happiness and Economics: How the Economy and Institutions Affect Well-Being. Princeton, NJ: Princeton University Press.

Frey, Bruno S. and Alois Stutzer (2002b). What Can Economists Learn from Happiness Research? Journal of Economic Literature 40(2): 402-35.

Galloway, Peter (2002). The Order of St Michael and St George. London: Third Millennium Publishing.

Ginsburgh, Victor (2003). Awards, Success and Aesthetic Quality in the Arts. Journal of Economic Perspectives 17(2): 99-111.

Ginsburgh, Victor A. and Jan C. van Ours (2003). Expert Opinion and Compensation: Evidence from a Musical Competition. American Economic Review 93(1): 289-296. 
Gneezy, Uri and Aldo Rustichini (2000a). A Fine Is a Price. Journal of Legal Studies 29(1): $1-14$.

Gneezy, Uri and Aldo Rustichini (2000b). Pay Enough or Don't Pay at All. Quarterly Journal of Economics 115(3): 791-810.

Goodin, Robert E. (1980). Manipulatory Politics. New Haven: Yale University Press.

Greene, Kenneth V. and Phillip J. Nelson (2002). The Market for Status. Working Paper, Department of Economics, Binghampton University.

Hennerberger, Melinda (2002). The Saints Just Keep Marching in. New York Times, March 3: 6.

Holden, Anthony (1993). The Oscars : the Secret History of Hollywood's Academy Awards. London: Little Brown and Company.

Holmstrom, Bengt and Paul Milgrom (1994). The Firm as an Incentive System. American Economic Review 84(4): 972-991.

Holmstrom, Bengt and Paul Milgrom (1991). Multitask Principal-Agent Analyses: Incentive Contracts, Asset Ownership, and Job Design. Journal of Law, Economics, and Organization 7(2): 24-52.

Honig, Werner (1986). Die Ehre Im Knopfloch. Orden und Ehrenzeichen Im Wandel der Zeiten. Berg.-Gladb.: Lübbe.

House of Commons, Select Committee on Public Administration (2004). A Matter of Honour: Reforming the Honours System. Fifth Report of Session 2003-04. London: Stationary Office.

Jeffrey, Scott (2004). The Benefits of Tangible Non-Monetary Incentives. Working Paper, Graduate School of Business, University of Chicago.

Kellerhoff, Sven F. (2004). Das Grosse Sterben. Die Welt, 4. August: 27.

Klietmann, Kurt-Gerhard and Ottfried Neubecker (1984). Ordens-Lexikon. Berlin.

Krebs, David, Paul Milgrom and Wilson Roberts (1982). Rational Cooperation in the Finitely Repeated Prisoner's Dilemma. Journal of Economic Theory 27: 245-252.

Krueger, Anne O. (1974). The Political Economy of the Rent-Seeking Society. American Economic Review 64(3): 291-303.

Layard, Richard (2005). Happiness: Lessons from a New Science. New York, NY: Penguin.

Levy, Emanuel (1987). And the Winner Is: the History and Politics of the Oscar Awards. New York: Ungar.

Lindbeck, Assar (1985). The Prize in Economic Science in Memory of Alfred Nobel. Journal of Economic Literature 23(1): 37-56.

Mericka, Vaclav and Jindrich Marco (1990). Das Buch der Orden und Auszeichnungen. 2. Hanau: Dauslen.

Miron, Jeffrey A. and Jeffrey Zwiebel (1995). The Economic Case against Drug Prohibition. Journal of Economic Perspectives 9(4): 175-192.

Murphy, Kevin M., Andrei Shleifer and Robert W. Vishny (1991). The Allocation of Talent: Implications for Growth. Quarterly Journal of Economics 106(2): 503-530.

Nasar, Sylvia (1998). A Beautiful Mind : a Biography of John Forbes Nash, Jr., Winner of the Nobel Prize in Economics, 1994. New York: Simon \& Schuster.

Nelson, Randy A., Michael R. Donihue, Donald Waldman and Cal Wheaton (2001). What's an Oscar Worth? Economic Inquiry 39(1): 1-16.

NZZ (2004). Neue Zürcher Zeitung, 3. November 2004: 63.

Olson, Mancur Jr. (1982). The Rise and Decline of Nations: Economic Growth Stagflation and Social Rigidities. New Haven: Yale University Press.

Osterloh, Margit and S. Frey Bruno (2000). Motivation, Knowledge Transfer, and Organizational Forms. Organization Science: A Journal of the Institute of Management Sciences 11(5): 538-550. 
Peacock, Alan and Ronald Weir (1975). The Composer in the Market Place: An Economic History. London: Faber.

Phillips, Sir Hayden (2004). Review of the Honours System. London: Cabinett Office.

Prendergast, Canice (1999). The Provision of Incentives in Firms. Journal of Economic Literature 37 1: 7-63.

Prendergast, Canice and Lars Stole (2001). The Non-Monetary Nature of Gifts. European Economic Review 45(10): 1793-1810.

Risk, James C. (1972). The History of the Order of the Bath and Its Insignia. London: Spink and Son.

Robertson, Megan (2005). Orders, Decorations and Medals of the United States of America. http://www.medals.org.uk/usa.

Rosen, Sherwin (1981). The Economics of Superstars. American Economic Review 71(5): 845-858.

Scitovsky, Tibor (1976). The Joyless Economy: An Inquiry into Human Satisfaction and Consumer Dissatisfaction. New York: Oxford University Press.

Spence, Michael A. (1974). Competitive and Optimal Responses to Signals: An Analysis of Efficiency and Distribution. Journal of Economic Theory 7(3): 296-332.

Steinberg, Jonathan (1996). Why Switzerland? Cambridge, UK: Cambridge University Press.

Stutzer, Alois (2004). The Role of Income Aspirations in Individual Happiness. Journal of Economic Behavior and Organization 54(1): 89-109.

Throsby, David C. and Glenn A. Withers (1979). The Economics of the Performing Arts. New York: St. Martin's Press.

Tirole, Jean (1996). A Theory of Collective Reputations (with Applications to the Persistence of Corruption and to Firm Quality). Review of Economic Studies 63(1): 1-22.

Tollison, Robert D. (1982). Rent Seeking: A Survey. Kyklos 35(4): 575-602.

Tollison, Robert D. and Roger D. Congleton (eds) (1995). The Economic Analysis of Rent Seeking. The International Library of Critical Writings in Economics, vol. 49. Aldershot, UK: Edward Elgar Publishing Limited.

Towse, Ruth (1993). Singers in the Marketplace : the Economics of the Singing Profession. Oxford [England]: Clarendon Press.

Towse, Ruth (2003). A Handbook of Cultural Economics. Northhampton, MA: Edward Elgar Pub.

Tullock, Gordon (1967). Welfare Costs of Tariffs, Monopolies, and Theft. Western Economic Journal 5(3): 224-232.

Waldfogel, Joel (1993). The Deadweight Loss of Christmas. American Economic Review 83(5): 1328-1336.

Walzer, Michael (1983). Spheres of Justice : a Defense of Pluralism and Equality. New York: Basic Books.

Ward, Melanie E. and Peter J. Sloane (2000). Non-Pecuniary Advantages Versus Pecuniary Disadvantages; Job Satisfaction among Male and Female Academics in Scottish Universities. Scottish Journal of Political Economy 47(3): 273-303.

Wijnberg, Nachoem M. (2003). Awards. In: Ruth Towse (ed.). Handbook of Cultural Economics. London: Edward Elgar: 81-88.

Young, H. Peyton (1993). The Evolution of Conventions. Econometrica 61(1): 57-84. 


\section{Appendix:}

\section{Contemporary Orders, Medals and Decorations}

\section{Australia}

- Victoria Cross of Australia

- Cross of Valour

- Order of the Garter*

- Order of the Thistle*

- Order of Merit*

- Order of Australia

- Royal Victorian Order*

- Star of Gallantry

- Star of Courage

- Distinguished Service Cross

- Conspicuous Service Cross

- Nursing Service Cross

- Medal for Gallantry

- Bravery Medal

- Distinguished Service Medal

- Public Service Medal

- Australian Police Medal

- Australian Fire Service Medal

- Ambulance Service Medal

- Emergency Services Medal

- Order of St John

- Conspicuous Service Medal

- Australian Antarctic Medal

- Commendation for Gallantry

- Commendation for Brave Conduct

- Commendation for Distinguished Service

- Queen's South Africa Medal

- King's South Africa Medal

- 1914 Star

- 1914-15 Star

- British War Medal

- Mercantile Marine War Medal

- Victory Medal

- Naval General Service Medal 1918-62

- General Service Medal 1918-62

- 1939-45 Star

- Atlantic Star

- Air Crew Europe Star

- Africa Star

- Pacific Star

- Burma Star

- Italy Star

- France and Germany Star

- Defence Medal

- War Medal

- Australia Service Medal 1939-45

- Australian Active Service Medal 1945-75

- Korea Medal

- UN Korea Medal

- General Service Medal 1962

- Vietnam Medal

- Vietnam Logistic and Support Medal

- Australian Active Service Medal

- International Force East Timor Medal 
- Iraq Medal

- Afghanistan Medal

- Australian Service Medal 1945-75

- Australian Service Medal

- Rhodesia Medal

- Police Overseas Service Medal

- Humanitarian Overseas Service Medal

- Civilian Service Medal 1939-45

- King Edward VII Coronation Medal

- King George V Coronation Medal

- King George V Silver Jubilee Medal

- King George VI Coronation Medal

- Queen Elizabeth II Coronation Medal

- Queen Elizabeth II Silver Jubilee Medal

- 80th Anniversary Armistice Remembrance Medal

- Australian Sports Medal

- Centenary Medal

- Defence Force Service Medal

- Reserve Force Decoration

- Reserve Force Medal

- Defence Long Service Medal

- National Medal

- Australian Cadet Forces Medal

- Champion Shots Medal

- Anniversary of National Service Medal

- UN Operation in Mozambique

- UN Mission for the Referendum in Western Sahara

\section{Austria}

\section{5-date}

- Decoration of Honour for Merit

- Honour Decoration of Steiermark

- Decoration of Honour for Science and the Arts

- Cross of Honour for Science and Art

- Teutonic Order

- Order of St John of Jerusalem and of Malta for the Grand Priorate of Austria and Bohemia

- Distinguished Service Cross for Emergency Services of Steiermark

- Steiermark Lifesaving Medal

- Steiermark Flood Medal

- UN Operation in Mozambique

- UN Mission for the Referendum in Western Sahara

- Olympic Medal 1964

- Olympic Medal 1976

- Long Service Medal

- Long Service Medal for Steiermark Emergency Services

\section{Belgium}

- The Order of Leopold I

- The Order of the African Star

- The Royal Order of the Lion

- The Order of the Crown

- The Order of Leopold II

- Military Decoration

- Industrial and Agricultural Decoration

- Civil Decoration for Bravery, Devotion and Philanthropy

- Iron Cross

- War Cross 1914-18 
- Yser Medal

- Yser Cross

- Maritime Decoration 1914-18

- Civil Decoration 1914-18

- King Albert Medal

- Queen Elisabeth Medal

- War Cross 1940-45

- Civil Decoration 1940-45

- Evader's Cross 1940-45

- Medal of Belgian Gratitude 1940-45

- Maritime Medal 1940-45

- War Cross 1954

- Medal of the Civil Guard

- Commemorative Cross of the 1830 Volunteers

- Medal of the Carnegie Hero Fund

- Commemorative Medal 1870-71

- Commemorative Medal of the Royal Visit to Brazil

- Commemorative Medal of the VIIth Olympics

- Commemorative Medal of the 75th Anniversary of the Postal Services

- Commemorative Medal for the Congo

- Commemorative Medal of the Reign of Leopold I

- Fire Cross 1914-18

- Volunteer Combatant's Medal 1914-18

- Victory Medal 1914-18

- Commemorative Medal of the War 1914-18

- Commemorative Medal of the African Campaigns 1914-17

- Medal for Political Prisoners 1914-18

- Deportee's Cross 1914-18

- Colonial Commemorative Medal 1914-18

- Medal of the National Committee for Aid and Nourishment 1914-18

- Medal of the National Restoration 1914-18

- Commemorative Medal of the 100th Anniversary of National Independence

- Commemorative Medal of the House of King Albert

- Medal for Physical Education and Sports

- Medal of Sports Merit

- Commemorative Medal of the 100th Anniversary of the Telegraphic Services

- Commemorative Medal of the 100th Anniversary of the Ostend-Dover Line

- Commemorative Medal of the 100th Anniversary of the Postal Services

- Resistance Medal 1940-45

- Political Prisoner's Cross 1940-45

- Volunteer's Medal 1940-45

- Commemorative Medal of the War 1940-45

- Prisoner of War Medal 1940-45

- Commemorative Medal of the Abyssinian Campaign

- African War Medal 1940-45

- Civil Resistance Medal

- Defaulter's Medal

- Deportee's Medal

- Medal for Colonial War Effort 1940-45

- Medal for Military Fighters of the War 1940-45

- Medal for the Resisters Against Nazism in the Annexed Territories

- World War Two Recruiting Centres Medal

- Commemorative Medal for Operations Abroad

- Medal of the War Volunteer

- UN Medal for Korea

- Commemorative Medal for Armed Humanitarian Operations

- Commemorative Medal for Foreign Missions or Operations

- Honour Cross for Military Service Abroad

- Military Decoration (Article 4)

- Military Cross 
- Service Star

- Civil Decoration for Long Service in the Administration

- Native Service Medal (civilian)

- Native Service Medal (military)

- Commemorative Medal of the Reign of Albert I

\section{Unofficial Awards}

- Liege Medal

- Cross of Honour of the Belgian Red Cross 1940-45

- Air Defence Medal

\section{Canada}

- Victoria Cross of Canada

- Cross of Valour

\section{National Orders}

- Order of Canada

- Order of Military Merit

- Order of Merit of the Police Forces

- Royal Victorian Order

- Order of St John

Provincial Orders

- Order of Quebec

- Saskatchewan Order of Merit

- Order of Ontario

- Order of British Columbia

- Alberta Order of Excellence

- Order of Prince Edward Island

- Order of Manitoba

- Order of New Brunswick

- Order of Nova Scotia

- Yukon Territory Order of Polaris

\section{Decorations}

- Star of Military Valour

- Star of Courage

- Meritorious Service Cross (Civil)

- Meritorious Service Cross (Military)

- Medal of Military Valour

- Medal of Bravery

- Meritorious Service Medal (Civil)

- Meritorious Service Medal (Military)

- Royal Victorian Medal

- Canada Medal

War and Operational Service Medals

- Africa General Service Medal 1902-56

- India General Service Medal 1908-35

- Naval General Service Medal 1915-62

- General Service Medal 1918-62

- 1914 Star

- 1914-15 Star

- British War Medal 1914-18

- Victory Medal

- Territorial Force War Medal

- 1939-45 Star

- Atlantic Star

- Air Crew Europe Star 
- Africa Star

- Pacific Star

- Burma Star

- Italy Star

- France and Germany Star

- Defence Medal

- Canadian Volunteer Service Medal

- Newfoundland Volunteer Service Medal

- War Medal 1939-45

- Canadian Korea Medal

- Canadian Volunteer Service Medal for Korea

- General Service Medal 1962

- Gulf and Kuwait Medal

- Somalia Medal

- South West Asia Service Medal

\section{Special Service Medals}

- Special Service Medal

- Canadian Peacekeeping Service Medal

\section{United Nations Medals}

- UN Korea Medal

- UNEF Medal

- Truce Supervision Organization in Palestine (1948- ) and Observer Group in Lebanon (1958)

- Military Observation Group in India and Pakistan (1948- )

- Operation in Congo (1960-64)

- Temporary Executive Authority in West New Guinea (1962-63)

- Yemen Observation Mission (1963-64)

- Force in Cyprus (1964- )

- India/Pakistan Observation Mission (1965-66)

- Emergency Force Middle East (1973-79)

- Disengagement Observation Force Golan Heights (1974- )

- Interim Force in Lebanon (1978- )

- Military Observation Group in Iran/Iraq (1988-91)

- Transition Assistance Group (Namibia) (1989-90)

- Observer Group in Central America (1989-92)

- Iraq/Kuwait Observer Mission (1991- )

- Angola Verification Mission (1988-97)

- Mission for the Referendum in Western Sahara (1991- )

- Observer Mission in El Salvador (1991-95)

- Protection Force (Yugoslavia) (1992-95)

- Advance Mission in Cambodia (1991-92)

- Transitional Authority in Cambodia (1992-93)

- Operation in Somalia (1992-93)

- Operation in Mozambique (1992-94)

- Observation Mission in Uganda/Rwanda (1993-94)

- Assistance Mission in Rwanda (1993-96)

- Mission in Haiti (1993- )

- Verification of Human Rights and Compliance with the Comprehensive Agreement on Human Rights in Guatemala (1997-98)

- Mission in the Central African Republic (1998-2000)

- Preventive Deployment Force (Macedonia) (1995-99)

- Mission in Bosnia and Herzegovina (1995- )

- Mission of Observers in Prevlaka (Croatia) (1996- )

- Interim Administration Mission in Kosovo (1999- )

- Special Service (1995- )

- Headquarters

\section{Denmark}


- The Order of the Elephant

- The Order of the Dannebrog

- The Medal of Merit

- The Medal for Heroic Deeds

- The Distinguished Flying Medal

- The Medal for Those Killed or Wounded in Service

- The Lifesaving Medal

- The 'Ingenio et Arte' Medal

- Medal of Merit of Greenland

- Medal for the Battle of Copenhagen 1801

- Commemorative War Medal of 1848-50

- Commemorative War Medal of 1864

- Schleswig Medal

- Commemorative Medal for Aid to Prisoners of War 1914-19

- Commemorative Medal for Aid to Sick and Wounded in the Finnish War 1939-40

- The Commemorative Medal of 9 April 1940

- King Christian the Tenth's Medal of Freedom

- King Christian the Tenth's Commemorative Medal for Service in the War 1940-45

- The Red Cross Commemorative Medal 1939-45

- Liberation Commemorative Medal

- Korea Medal

- The Red Cross Commemorative Medal for Participation in the Exchange of Prisoners of War in Korea 1953

- The Defence Medal

- International Conference on the Former Yugoslavia Medal

- Iraq Mission Medal

- IFOR and SFOR Police Special Performance Award

- The Navy Long Service Medal

- The Army Long Service Medal

- The Air Force Long Service Medal

- The Medal for Long Service in the Department of Defence

- The Medal for Good Service in the Reserve Forces

- Reserve Preparedness Medal

- The Long Service Cross

- The Police Good Service Medal

- The Civil Defence Good Service Medal

- The Home Guard Good Service Medal

- Firemen's Good Service Medal

- The Home Guard 40 years' Service Decoration

- The Home Guard 25 years' Service Decoration

- Home Guard 50 years' Jubilee Medal

- The Commemorative Medal for the Gold Wedding of King Christian IX and Queen Louise (1892)

- The Commemorative Medal on the Occasion of the Silver Wedding of HM The Queen and HRH The Prince Consort (1992)

- The Silver Jubilee Medal of Queen Margrethe of Denmark

- Honour Badge of the Danish Reserve Officers' Association

- Honour Badge of the League of Civil Defence

- King Christian X's Medal of Recompense

- The Queen's Medal of Recompense

- Danish National Travel Association Medal

- Medal of Merit of the Chamber of Danish Handicraft

- Danish Red Cross Badge of Honour

- Danish Red Cross Service Medal

- DANCON March Medal

\section{Unofficial Awards}

- The Freedom Foundation's commemorative badge

- The Commemorative Cross of the Danish Brigade Association (Danforce)

- The Commemorative Medal of the Veterans of the Freedom Fight association

\section{France}


- Legion of Honour

- Order of Liberation

- National Order of Merit

- Military Medal

- War Cross 1914-18

- War Cross 1939-45

- War Cross for Operations Overseas

- Cross for Military Valour

- Cross for Volunteers 1914-18

- Resistance Medal

- Cross for Volunteers in the Resistance

- Medal for Voluntary Service in the Free French Forces

- War Commemorative Medal 1939-45

- Commemorative Medal for the Italian Campaign

- Gratitude Medal

- Cross for Volunteers 1939-45

- Medal of Liberated France

- Medal of the Patriot

- Medal for those Deported or Interned for Resistance Activities

- Medal for those Deported or Interned for Political Activities

- North African Campaign Medal

- Medal of Honour for the Railways

\section{Germany}

The German Democratic Republic (1945-90)

- Order of Karl Marx

- Order of the Star of Friendship of Nations

- Hero of the German Democratic Republic

- Hero of Labour

- Fatherland's Order of Merit

- Distinguished Scientist of the Nation

- National Prize of German Democratic Republic

- Order of Banner of Labour

- Order of Scharnhorst

- Order for Merit for the Nation and Fatherland

- Blucher Order for Gallantry

- Gallantry Medal

- Order of Military Merit

- Medal of Military Merit

- Medal for Participants of Armed Campaigns of German Working Class

- Medal for Fighters against Fascism

- Medal of Hans Beimler

- Medal of Clara Zetkin

- Medal of Merit of the German Democratic Republic

- Cosmonaut-Pilot of German Democratic Republic

- Meritorious Military Pilot

- Meritorious Member of National People's Army

- Meritorious Member of Border Guards

- Meritorious Member of Civil Defense

- Meritorious Member of State Security

- Meritorious Policeman

- Meritorious Member of Customs

- Friedrich Engel's Prize

- Theodor Köner Prize

- National People's Army Medal of Merit

- Border Troops Medal of Merit

- Civil Defense Medal of Merit 
- Decoration of German Police

- Organs of Ministry of Interior Medal of Merit

- Fighting Groups of Working Class Medal of Merit

- Customs Medal of Merit

- Medal for Exemplary Border Service

- Brotherhood in Arms Medal

- Medal for Merit in Fire Protection

- Militarized Organs of Ministry of Interior Outstanding Service Medal

- Fighting Groups of Working Class Outstanding Service Medal

- Fire Protection Distinguished Service Medal

- Decoration for Merit for Reserve Service

- 20th Anniversary of Democratic Land Reform Commemorative Medal

- 20th Anniversary of the Foundation of Fighting Groups of Working Class Commemorative Medal

- 30th Anniversary of Foundation of GDR Medal

- 30th Anniversary of National People's Army

- 40th Anniversary of GDR Medal

- Medal for Long Service

- Medal for Long Service in Barracked Police

- Medal for Long Service in Militarized Organs of Ministry of Interior

- Medal for Long Service in Fighting Groups of Working Class

- Medal for Long Service in Customs

- Reserve Badge of National People's Army

- Meritorious Technician of the Nation

- Meritorious Inventor

- Meritorious Miner

- Meritorious Worker of Energy Industry

- Meritorious Worker of Iron Industry

- Meritorious Worker of Chemical Industry

- Meritorious Worker of Metal Industry

- Meritorious Worker of Light \& Food Industry

- Meritorious Worker of Communal and Accommodation Services

- Meritorious Worker of Construction Industry

- Meritorious Transportation Worker

- Meritorious Railroadman

- Meritorious Mariner

- Meritorious Worker of Mail and Communications Services

- Meritorious Collective Farmer

- Meritorious Forestry Worker

- Meritorious Worker of Water Industry

- Meritorious Breeder

- Meritorious Veterinary Doctor

- Meritorious Trade Worker

- Meritorious Financial Worker

- Meritorious Worker of Planning Organs

- Meritorious Worker of Foreign Services

- Meritorious Teacher

- Meritorious Academic Teacher

- Meritorious Medical Doctor

- Meritorious Worker of Health Service

- Meritorious Lawyer

- Meritorious People's Controller

- Architecture Prize of GDR

- Design Prize of GDR

- Art Prize of GDR

- Johannes R. Becher Prize

- Lessing Prize

- Heinrich Heine Prize

- Heinrich Greif Prize

- Prize for Folk Artists

- Cisinski Prize 
- Decoration for Physical Culture and Sports

- Meritorious Champion

- Medal for Distinguished Service in the Energy Industry

- Medal for Distinguished Service in Geology

- Medal for Distinguished Service in Iron Industry

- Medal for Distinguished Service in Chemical Industry

- Medal for Distinguished Service in Metal Industry

- Medal for Distinguished Service in Light and Food Industry

- Medal for Distinguished Service in Communal and Accommodation Services

- Medal for Distinguished Service in Construction

- Medal for Distinguished Service in Transportation

- Medal for Distinguished Service in Collective Farming

- Medal for Distinguished Service in Forestry

- Medal for Distinguished Service in Water Industry

- Medal for Distinguished Service in Trade

- Medal for Distinguished Service in Finances

- Medal for Distinguished Service in Economic Planning

- Medal for Distinguished Service in Foreign Service

- Meritorious Master

- Meritorious Activist

- Medal for Outstanding Service in Socialist Competition

- Distinguished Youth Brigade/Collective

- Distinguished Youth Activist

- Medal for Distinguished Service in the Champion of Tomorrow Movement

- Karl Liebknecht Medal

- Champion Miner

- Distinguished Collective Farmer

- Champion of Collective Farming

- Champion Farmer

- Medal for Merit in Mining Industry

- Medal for Merit in Energy Industry

- Medal for Merit in Forestry

- Johannes Dobberstein Medal for Merit in Veterinary Medicine

- Medal for Merit for German Railroads

- Medal for Merit in Sea Transport

- Medal for Merit in German Postal Service

- Helene Weigel Medal

- Lessing Medal

- Dr.Theodor Neubauer Medal

- Humboldts Medal

- Kurt Barthel Medal

- Hufeland Medal

- Friedrich Wolf Medal

- Medal for Merit in Legal Service

- Medal for Merit in People's Control

- Medal for Merit in Mine Rescue

- Life Saving Medal

- Medal for Selfless Service in Fighting Disasters

- Medal for Merit for Folk Artists

- Collective of Socialist Labour

- Community of Socialist Labour

- Brigade of Socialist Labour

- Activist of Socialist Labour

- Activist of Seven Year Plan

- Activist of Five Year Plan

- Activist of Two Year Plan

- Activist

- Medal for Outstanding Service

- Medal for Outstanding Service in Collective Farming

- Medal for Exemplary Learning Collective in Socialist Competition 
- Medal for Very Good Service in Socialist Competition

- Carl Friedrich Wilhelm Wander Medal

- 20th Anniversary of Democratic Land Reform Commemorative Medal

- 30th Anniversary of Foundation of GDR Medal

- 40th Anniversary of GDR Medal

- Medal for Merit for FDJ Headquarters in Berlin

- Medal for Fighting Flood Disaster in July 1954

- Medal for Long Service for German Railroads

- Medal for Long Service in Sea Transport

- Medal for Long Service in Civil Aviation

- German Postal Service Long Service Medal

- Pestalozzi Medal for Long Service

- Medal for Long Service in Health and Social Service

- Medal for Long Work for Civil Defense

- Medal for Long Work for Strengthening Country Defense Power

- Medal for Long Service in Voluntary Fire Service

- Medal for Long Service for Voluntary Helpers in Guarding State Borders

- Frick Heckert Medal

- Art Prize

- Journalist Prize

- Hermann Dunker Medal

- Builder of Berlin Commemorative Medal

\section{The Federal Republic of Germany (1945-date)}

- Order of Merit of the Federal Republic of Germany

- Honour Cross of the German Armed Forces

- Oder Flood Medal 1997

- Military Service Medal

- Westphalia Fireman's Merit Cross

- Honour Medal of the Armed Forces

- Medal for Assistance During the 1962 Hamburg Flood

- Federal Medal of Merit

- Medal for Sport

\section{Italy}

\section{Italian Republic, 1946-date}

- Military Order of Italy

- Medal for Military Valour

- Medal for Army Valour

- Medal for Naval Valour

- Medal for Aerial Valour

- Medal for Valour for the Carabiniere

- Medal for Civilian Valour

- Cross of Military Valour

- War Merit Cross

- Army Merit Cross

- Medal for Naval Merit

- Medal for Aerial Merit

- Cross of Merit of the Carabiniere

- Medal for Civilian Merit

- Volunteers of Liberty Decoration

- Order of Merit of the Italian Republic

- Order of the Star of Italian Solidarity

- Order of Vittorio Veneto

- Order of SS. Maurice and Lazarus

- Order of the Crown of Italy

- Mauritian Medal for 50 years of Military Service 
- Grand Cross of Merit of the Italian Red Cross

- Italian Red Cross Medal of Merit for War Service

- Italian Red Cross Medal of Merit

- Army Long Command Medal of Merit

- Naval Long Command Medal of Honour

- Long Air Command Military Medal

- Financial Guard Long Command Medal of Merit

- Public Security Long Command Medal

- State Police Meritorious Service Medal

- Military Paratroops Long Service Medal of Merit

- Long Service Cross - Officers \& NCOs, 40 Years of Service

- State Police Long Service Cross

- Financial Guard Long Service Cross of Merit

- Long Service Cross - Officers \& NCOs, 25 Years of Service

- Public Security Long Service Cross

- Italian Red Cross Long Service Cross

- Long Service Cross - NCOs, 25 Years

- Long Service Cross - 16 Years

- Firefighters Long Service Cross

- Star of Labor Merit

- Medal of Merit for Public Health Service

- Medal of Merit for Education, Culture \& Arts

- Medal of Merit for Culture \& Arts

- Medal of Merit for Sciences \& Culture

- Medal of Merit for Public Finances

- Medal for 40 Years of Work in Elementary Schools

- Medal for Long Work in Elementary \& Children Education

- Commemorative Cross for the Operations in the Persian Gulf 1991

- Commemorative Cross for the Operations in Somalia

- Commemorative Cross for the Peace mission UNIFIL, UNTSO in Lebanon

- Commemorative Medal for the Navy personnel in Persian Gulf 1988

- Commemorative Cross for Peace Missions

- Commemorative Cross for Humanitarian Service

- Commemorative Cross for the Operations in Macedonia and Albania

- Commemorative Cross for the "Sicilian Vespers" Operation

- Commemorative Cross for the Operations to Restore Public Order

- Commemorative Cross for the Operations in Afghanistan

- Commemorative Medal for the "Arcobaleno" Operation

- Commemorative Medal for the Earthquake Rescue Operation in Friuli 1976

- Commemorative Medal for the Earthquake Rescue Operation in Campania 1980

- Commemorative Medal for participating in Rescue Operations in Public Calamities

- Commemorative Medal for the Etna Emergency 1991-92

- Commemorative Medal for the Emergency in Umbria \& Marche 1997

- Commemorative Medal for the Flood Rescue Operation in Piemont

- Commemorative Medal for the Antarctic Expedition

- Medal of Athletic Valour

\section{Japan}

- Order of the Chrysanthemum

- Order of the Rising Sun

- Order of the Precious Crown

- Order of the Sacred Treasure

- Order of the Golden Kite

- Order of Culture

- Medal of Honour with Yellow Ribbon

- Medal of Honour with Purple Ribbon

- Medal of Honour with Blue Ribbon

- Medal of Honour with Red Ribbon

- Medal of Honour with Green Ribbon 
- Medal of Honour with Dark Blue Ribbon

- 1874 Formosa Expedition War Medal

- 1894-95 Sino-Japanese War Medal

- 1900 Boxer War Medal

- 1904-05 Russo-Japanese War Medal

- 1914-20 First World War Medal

- Allied First World War Victory Medal

- 1931-34 China Incident War Medal

- 1937-45 China Incident War Medal

- 1939 Border War Medal

- 1942 China Incident War Medal

- 1941-45 Great East Asia War Medal

- Imperial Constitution Promulgation Medal

- 25th Wedding Anniversary Medal

- Crown Prince's Voyage to Korea Commemorative Medal

- Korea Annexation Commemorative Medal

- First National Census Medal

- Capital Rehabilitation Commemorative Medal

- Korean Census Commemorative Medal

- 2600th National Anniversary Commemorative Medal

- Taisho Enthronement Medal

- Showa Enthronement Medal

- National Foundation Merit Medal

- Imperial Visit to Japan Commemorative Medal

- National Shrine Foundation Commemorative Medal

- Red Cross Membership Medal

- Red Cross Order of Merit

- Imperial Sea Disaster Rescue Society Medal

- Next of Kin Medal

\section{Netherlands}

\section{Orders}

- Military Order of William

- Order of the Dutch Lion

- Order of Oranje-Nassau

- Order of the Oak Crown

- Order of the Golden Lion of Nassau

- House Order of Oranje

- Order of the Crown

Decorations

- Cross for Courage and Loyalty

- Medal for Courage and Loyalty

- Resistance Cross

- Medal for Humane Actions

- Honourable Mention

- Bronze Cross

- Flying Cross

- Cross of Merit

- Bronze Lion

- Resistance Star East Asia

- De Ruyter Medal

- Medal of the Red Cross

- Museum Medal

- Flood Medal

- Medal of Gratitude

- Medal for Native Civil Merit

- Star for Loyalty and Merit

- Award for Merit 


\section{Service Medals}

- Silver Commemorative Cross 1813-15

- Liberation of Den Briel Medal 1813

- Capture of Fort Duquesne Medal 1813

- Capture of Bois-Le Duc Medal 1814

- Breda Medal for Important Military Service 1813

- Dordrecht Volunteers' Medal 1813

- The Hague Volunteers' Medal 1813

- Siege of Naarden Medal 1814

- Defence of Brussels Medal 1815

- Medal to the Friesian Volunteer Riflemen 1815

- Java War Medal 1825-30

- Metal Cross 1830-31

- Metal Cross Volunteers 1830-31

- Siege of Antwerp Medal

- Expedition Cross

- Atjeh War Medal 1873-74

- Lombok Cross 1894

- War Commemorative Cross 1940-45

- Resistance Commemoration Cross

- Star for Order and Peace

- New Guinea Commemorative Cross

- Mobilisation War Cross 1939-45

- Cross for Justice and Liberty

- Medal for UN Peace Operations

- Medal for Multinational Peace Operations

- Kosovo Medal

- Medal for Humanitarian Services After Disasters

- The Commemorative Medal for Peacekeeping Operations

\section{Long Service Awards}

- Officers' Cross

- Officers' Cross for the Naval Engineering Service

- Officers' Cross for Naval Reserve and Militia

- NCOs' Long Service Medal

- County Constabulary Long Service Medal

- Volunteer Medal

- Volunteer Medal for Public Order and Safety

\section{Royal Commemoratives}

- Inauguration Medal 1898

- Wedding Medal 1901

- Silver Wedding Medal 1926

- Honour Guard Medal 1933

- Wedding Medal 1937

- Inauguration Medal 1938

- Silver Wedding Medal 1962

- Wedding Medal 1966

- Inauguration Medal 1980

- Medal for the Royal Visit Netherlands-Antilles 1980

- The Commemorative Medal for Foreign Visits

\section{Other Medals}

- Commemorative Medal for the Peace Conference in the Hague 1907

- Royal Prize for Shooting Matches

- Medal for Marksmen 1st Class

- Master Sharpshooter Insignia

- Royal Netherlands Navy Mastergunner Insignia

- Proficiency Medal of the Royal Netherlands-Indies Army 
- Shooting Prize Star

- Proficiency Medal of the Royal Netherlands Brigade 'Princess Irene'

- Navy Medal

- Commemorative Medal Voluntary Police 1948-98

\section{Miscellaneous}

- Sovereign Order of Malta, Dutch Baliwick

- Johanniter Order in the Netherlands

- Sovereign Order of St Jacob of Holland

- Silver Carnation

- Princely Order of the Golden Ark

- Rescue Medal Queen Emma

- Carnegie Hero Fund Medal

- Police Medal for Service in the Amsterdam Municipal Police

- Cross of Merit of the Netherlands Red Cross

- Medal of Merit of the Netherlands Red Cross

- Medal for Faithful Service in the Netherlands Red Cross

- Commemorative Cross 1939-45 of the Netherlands Red Cross

- Commemorative Cross 1940-45 of the Netherlands Red Cross

- Blood Donor's Medal of the Netherlands Red Cross

- Marching Cross

- Caretakers' Medal

- Gold Proficiency Medal of the NSF

- Gold Proficiency Medal of the NOC

- Proficiency Medal of the NOC/NSF

- National Pentathlon Cross

- Royal Netherlands Aeronautical Society Medal

- Medal of the Netherlands-Indies Aeronautical Society

- Cross of Merit of the Netherlands League of Volunteer Home Guards

- Medal for Special Zeal of the Netherlands League of Volunteer Home Guards

- Medal of Honour of the Amsterdam Volunteer Home Guard

- Cross for the Formerly Mobilised Amsterdam Volunteer Home Guard 1914-18

- HLO/NOC Badge

- Cross for Long Service with the Fire Department

- Commemorative Medal Youth Fire Department

- Medal of the Netherlands Fire Department

- Medal for Faithful Police Service

- Cross for Faithful Police Service

- Faithful Service Medal Surinam Police

- Police Cross for the Inauguration Celebrations 1898

- Police Medal for the Railway Strike 1903

- Police Cross for the Jubilee Celebrations 1923

- Police Medal for the Engagement Celebrations 1936

- Police Cross for the Jubilee Celebrations 1938

- Police Cross for the Inauguration Celebrations 1948

- Police Proficiency Medal

- Police Swimming Proficiency Medal

- Cross of Honour of the Amsterdam Police Gymnastics and Sports Society

- Medal of the South Holland Life Saving Society

- Faithful Service Medal of the South Holland Life Saving Society

- Medal of the North and South Holland Life Saving Society

- Commemorative Medal 1939-45 of the North and South Holland Life Saving Society

- Medal of the Life Saving Society

- KXIII Surveying Medal

- Cross of the Royal Netherlands Officers' Reserve Association

- Prince Maurice Medal of the Royal Netherlands Army Society

- Medal of Special Merit of the Royal Netherlands Air Force Society

- Mobilisation Cross 1914-18

- White Mobilisation Cross 1914-18

- Cross of Merit of the National Organisation 'The Mobilisation Cross' 
- Honswijk Fortress Commemorative Medal 1914

- Honswijk Fortress Reunion Cross 1934

- Air Raid Precaution Commemorative Medal 1940-45

- Cross and Medal of the Society of Dutch Military War and Service Victims

- Airborne March Medal of the Police Sports Association Renkum

- Major J.J. Vermuelen March of the Military Police Force

- Life Saver Course Proficiency Insignia

\section{New Zealand}

- Victoria Cross for New Zealand

- New Zealand Cross

- Original New Zealand Cross

- Order of the Garter*

- Order of the Thistle*

- Order of New Zealand

- New Zealand Order of Merit

- Royal Victorian Order*

- New Zealand Gallantry Star

- New Zealand Bravery Star

- Queen's Service Order

- New Zealand Gallantry Decoration

- New Zealand Bravery Decoration

- New Zealand Gallantry Medal

- New Zealand Bravery Medal

- Queen's Service Medal

- New Zealand War Service Medal 1939-45

- New Zealand Service Medal 1946-49

- Korea Medal

- UN Korea Medal

- Vietnam Medal (1968-73)

- $\quad$ General Service Medal (Peacekeeping) 1992

- General Service Medal (War-like Operations) 1992

- East Timor Medal

- International Force East Timor Medal

- Operational Service Medal

- General Service Medal 2001

- New Zealand Special Service Medal

- 1990 Commemorative Medal

- Suffrage Centennial Medal

- New Zealand Meritorious Service Medal

- New Zealand Armed Forces Award

- New Zealand Navy Long Service and Good Conduct Medal

- New Zealand Army Long Service and Good Conduct Medal

- New Zealand Air Force Long Service and Good Conduct Medal

- New Zealand Police Long Service and Good Conduct Medal

- New Zealand Fire Brigades Long Service and Good Conduct Medal

- New Zealand Prison Service Medal

- Ministry of Transport Long Service Medal

- Efficiency Decoration

- Efficiency Medal

- Royal New Zealand Naval Reserve Decoration

- Royal New Zealand Naval Volunteer Reserve Decoration

- Royal New Zealand Naval Reserve Long Service and Good Conduct Medal

- Royal New Zealand Volunteer Naval Reserve Long Service and Good Conduct Medal

- Air Efficiency Award

- The Queen's Medal (for Champion Shots of the New Zealand Naval Forces)

- The Queen's Medal (for Champion Shots in the Military Forces)

- The Queen's Medal (for Champion Shots of the Air Force)

- Cadet Forces Medal 
- The New Zealand Memorial Cross

Medals Awarded by Organisations

- The New Zealand United Fire Brigades Association: Gold Star

- The New Zealand United Fire Brigades Association: 5 Year Service Medal

- The Wellington Free Ambulance Long Service Medal

Citizens of New Zealand are also eligible for the award of numerous UK orders, decorations and medals; although the establishment of purely New Zealand awards as detailed above is designed to replace many of the UK awards previously used. Holders of UK awards may continue to wear them and use the associated titles and post-nominal letters.

\section{Russia}

The USSR (1917-1991)

\section{Titles of Distinction}

- The Gold Star Medal of Hero of the Soviet Union

- The Gold Star Medal of Hero of Socialist Work

\section{Orders}

- The Order of Victory

- The Order of Lenin

- The Order of the October Revolution

- The Order of the Red Banner

- The Order of Suvorov

- The Order of Ushakov

- The Order of Kutuzov

- The Order of Nakhimov

- The Order of Bogdan Khmelnitsky

- The Order of Alexander Nevsky

- The Order of the Patriotic War

- The Order of the Red Banner of Labour

- The Order of Friendship

- The Order of the Red Star

- The Order of Service to the Motherland

- The Order of Honour

- The Order of Glory

- The Order of Personal Courage

- The Order of Labour Glory

- The Order of Mother Heroine

- The Order of Maternal Glory

\section{Medals}

- Medal of Ushakov

- Medal of Nakhimov

- Medal for the 20th Anniversary of the Red Army

- Medal for Partisans of the Patriotic War

- Medal for Rescuing a Drowning Person

- Medal for Maintaining Public Order

- Medal for Military Cooperation

- Medal for Safeguarding the Frontiers

- Medal for Bravery in Firefighting

- Medal for Bravery

- Medal for Combat Service

- Medal for Valiant Labour

- Medal for Distinguished Labour

- Medal for the Restoration of the Donbass Mines

- Medal for the Restoration of Black Metallurgical Enterprises

- Medal for the Development of Virgin Lands 
- Medal for Development of the Non-Black Earth Regions of the USSR

- Medal for the Development of the Petrochemical Complex of Western Siberia

- Medal for Construction of the Baikul-Amur Railway

- Medal for 50 Year Anniversary of the Soviet Militia

- Medal for the Defence of Odessa

- Medal for the Defence of Sevastopol

- Medal for the Defence of the Soviet Arctic

- Medal for the Defence of the Caucasus

- Medal for the Defence of Kiev

- Medal for the Defence of Leningrad

- Medal for the Defence of Moscow

- Medal for the Defence of Stalingrad

- Medal for the Capture of Vienna

- Medal for the Capture of Budapest

- Medal for the Capture of Koenigsburg

- Medal for the Capture of Berlin

- Medal for the Liberation of Belgrade

- Medal for the Liberation of Prague

- Medal for the Liberation of Warsaw

- Medal for Victory over Germany

- Medal for Victory over Japan

- Medal for Valiant Labour in the Patriotic War

- Medal for Distinguished Military Service

- Medal for Armed Forces Veteran of the USSR

- Medal for the 100th Anniversary of Lenin's Birth

- Medal for Veterans of Labour

- Medal for the 20th Anniversary of Victory in the Great Patriotic War

- Medal for the 30th Anniversary of Victory in the Great Patriotic War

- Medal for the 40th Anniversary of Victory in the Great Patriotic War

- Medal for 30 Years of the Soviet Army and Navy

- Medal for 40 Years of the Armed Forces of the USSR

- Medal for 50 Years of the Armed Forces of the USSR

- Medal for 60 Years of the Armed Forces of the USSR

- Medal for 70 Years of the Armed Forces of the USSR

- Medal Commemorating the 800th Anniversary of Moscow

- Medal Commemorating the 250th Anniversary of Leningrad

- Medal Commemorating the 1500th Anniversary of Kiev

- Motherhood Medal

- Medal for 10 Years Irreproachable Service in the Armed Forces of the USSR

- Medal for 15 Years Irreproachable Service in the Armed Forces of the USSR

- Medal for 20 Years Irreproachable Service in the Armed Forces of the USSR

The Russian Federation (1991-date)

- Gold Star Medal of Hero of the Russian Federation

- Order of St Andrew

- Order of St George

- Order of Merit for the Motherland

- Order of Zhukov

- Order for Personal Courage

- Order of Suvorov

- Order of Ushakov

- Order of Kutuzov

- Order of Alexander Nevsky

- Order of Nakhimov

- Order of Bravery

- Order of Military Merit

- Order of Naval Merit

- Order of Honour

- Order of People's Friendship 
- Order of Friendship

- Medal of the Order of Merit for the Motherland

- Bravery Medal

- Life Saving Medal

- Suvorov Medal

- Ushakov Medal

- Nyestyerov Medal

- Medal for Distinguished Service in Defence of the State Frontier

- Medal for Distinguished Service in Defence of Public Order

- Zhukov Medal

- Jubilee Medal for 300 Years of the Russian Navy

- Medal for 850th Anniversary of Moscow

- Medal of Pushkin

- Medal for the Defender of Free Russia

- Jubilee Medal for 50th Anniversary of Victory in the Great Patriotic War

- Jubilee Medal for 100th Anniversary of the Trans-Siberian Railway

- Ministry of Defence Medal for Participation in the Bosnia-Kosovo Raid 12 June 1999

- Ministry of Defence Medal for Military Valour

- Ministry of Defence Medal for Labour Valour

- Ministry of Defence Medal for Distinguished Military Service

- Ministry of Defence Medal for Strengthening of Brotherhood of Arms

- Ministry of Defence Medal for Zeal in Performing Engineering Troops Orders

- Ministry of Defence Mine Clearing Medal

- Ministry of Defence Badge for Service in Military Intelligence

- Ministry of Defence Medal for 200th Anniversary of Ministry of Defence

- Ministry of Defence Medal for 70th Anniversary of Airborne Troops

- Interior Ministry Medal for Military Valour

- Interior Ministry Medal for Valour in Service

- Interior Ministry Medal for Distinguished Service

- Interior Ministry Medal for Strengthening of Brotherhood of Arms

- Interior Ministry Medal for Bravery in Fire

- Interior Ministry Badge for Veteran of Economical Criminal Service

- Interior Ministry Medal for the 200th Anniversary of the Interior Ministry

- Interior Ministry Medal for the 80th Anniversary of Northern-Western Transport UVD

- Federal Security Service Medal for Distinguished Military Service

- Federal Security Service Medal for Strengthening of Brotherhood of Arms

- Federal Guarding Service Medal for Distinguished Military Service

- Federal Frontier Service Cross for Service in the Caucasas

- Federal Frontier Service Cross for Service in Tadjikistan

- Federal Frontier Service Medal for Participant in Operations

- Federal Frontier Service Medal for Distinguished Military Service

- Federal Frontier Service Medal for Strengthening of Brotherhood of Arms

- Ministry of Justice Medal of Koni

- Ministry of Justice Medal for Zeal

- Ministry of Justice Medal for Valour

- Ministry of Justice Medal for Service

- Ministry of Justice Medal for Strengthening of Penitentiary Service

- Ministry of Justice Medal for Veterans of Penitentiary Service

- Ministry of Extraordinary Situations Cross of Merit

- Ministry of Extraordinary Situations Medal for Lensk Recovery

- Ministry of Extraordinary Situations Medal for Irreproachable Service

- Ministry of Extraordinary Situations Medal for Distinguished Military Service

- Intelligence Service Medal for Distinguished Military Service

- Federal Agency of Government Telecommunications and Information Medal for Distinguished Military Service

- Federal Agency of Government Telecommunications and Information Medal for Distinguished Labour

- Federal Agency of Government Telecommunications and Information Medal for Strengthening of Brotherhood of Arms

- Ministry of Railroads Medal for 150th Anniversary of St Petersburg-Moscow Railroad

- Federal Service of Railroad Troops Medal for Distinguished Service 
- Federal Service of Railroad Troops Medal for Irreproachable Service

- Federal Service of Railroad Troops Badge for Veteran of Railroad Troops

- State Messenger Service Medal for Fidelity to Duty

- State Messenger Service Medal for Irreproachable Service

- State Customs Service Medal for Strengthening of Customs Union

- State Customs Service Medal for Service in Customs

- Medal 'Glory of Adygeya'

- Medal for Merit of Republic of Adygeya

- Medal for Defence of Osetya

- Medal for Arctic Service

- Medal for Contributing to Strengthening of Law and Order and Legality

- Medal for Deserving Worker in Resorts and Tourism

- Cross for Works and Fatherland

- Medal for the 60th Anniversary of Battle for Moscow

- Medal for the 55th Anniversary of the Battle of Kursk

- Medal for the 10th Anniversary of the North-Western Customs Department

- Medal for the 160th Anniversary of the Samara Fire Service

\section{Unofficial Medals}

- Cossak Medal of Defender of the Country

- Cross for Service to Cossacks

- Cross for Revival of Siberian Cossacks

- Medal for the 10th Anniversary of the Cossack Union

- Cossack Cross for Faith and Fatherland

- Medal of Merit of Volga Cossacks

- Volga Cossack Medal for Distinguished Service

- Volga Cossack Medal for Service in Cossack Troops

- Jakut Cossack Medal of Beketov

- Medal for the 300th Anniversary of the Jakut Cossack Regiment

- Medal for the 10th Anniversary of the Revival of the Orenburg Cossacks

- Medal of the Amur Cossacks

- Cross for Service in the Caucasus

- Medal of Russian Union of Afghan Veterans

- Medal for the 10th Anniversary of the Withdrawal of Soviet Troops from Afghanistan

- Medal for Veterans of the Cold War at Sea

- Medal for the 60th Anniversary of the 16th Guards Karachevskaya Infantry Division

- Medal 'Pro Fide'

- Medal 'Grace Heaven'

- Medal for Sacrificial Service

- Order of Spiritual Awakening

- Medal 'Sovereign Emperor the All-Russian Autocrat Nikolay II'

- Medal 'Mother of Defender of the Country'

- Medal for Participants in the Lifting of the Kursk

- Medal in Memory of the Lifting of the Kursk

- Medal in Memory of Chernobyl

- Medal 'Adherent of Education'

- Rybakov Prize Medal

- Medal of FNCA 'Russian Germans'

- Medal for the 750th Anniversary of Alexander Nevsky's Victories

- Medal for the 300th Anniversary of the Semenovsky Regiment

- Medal for the 120th Anniversary of Russian Divers

- Medal for the 175th Anniversary of the Naval Academy

- Medal for the 300th Anniversary of the St Petersburg Naval Institute

- Medal for the 300th Anniversary of the St Petersburg Grand Synagogue

- Medal for the 175th Anniversary of the Proletarsky Plant

- Medal for the 50th Anniversary of the Navy School

- Medal for Merit of the Military Magazine 'Sergeant'

Medals issued by the ex-Presidium of the Supreme Soviet of the USSR

- Order for Defender of Freedom 
- Order of Stalin

- Medal for 50th Anniversary of Victory 1941-45

- Medal for 55th Anniversary of Victory 1941-45

- Medal 'Marshal of Soviet Union Zhukov'

- Medal for the 80th Anniversary of the Great October Socialist Revolution

- Medal for the 80th Anniversary of the Armed Forces of the USSR

- Medal 'Fleet Admiral of the Soviet Union Kuznetzov'

- Medal for the 80th Anniversary of Frontier Troops of the USSR

- Medal for the 50th Anniversary of Nuclear Power Engineering in the USSR

- Medal for the 80th Anniversary of the Cheka/KGB

- Medal for the 80th Anniversary of the VLKSM

- Medal for the 120th Anniversary of I.V. Stalin

- Medal for Veteran Internationalist

- Medal for the 70th Anniversary of Airborne Troops of the USSR

\section{Sweden}

- Order of the Seraphim

- Order of the Sword

- Order of the Northern Star

- Order of Vasa

- Seraphim Medal

- Badge of the Sword

- Medal of the Sword

- Knight of the Grand Cross of the Order of the Sword

- War Cross of the Order of the Sword

- Royal Badge of Vasa

- Royal Medal of Vasa

- Order of Charles XIII

- Order of St John of Sweden

- Commemorative Medal for King Gustav V

- Commemorative Medal for King Gustav VI Adolf

- Crown Prince Gustav \& Princess Victoria Silver Wedding Anniversary medal 1906

- King Oscar \& Queen Sophia Golden Wedding Anniversary medal 1907

- Gustav V 70th Birthday decoration

- Gustav V 80th Birthday decoration

- Gustav V 90th Birthday breast badge

- Royal Household medal Oscar II

- Royal Household medal Gustav V

- Royal Household medal Gustav VI

- Royal Medal for Zeal and Honour Gustav V

- Royal Medal for Zeal and Honour Gustav VI

- Gustav V Olympic Medal 1912

- Gustav V Foundation of Sweden medal 1638-1938

- Red Cross merit Decoration

- Gustav V Red Cross Merit medal for Volunteers

- Gustav VI Red Cross Merit medal for Volunteers

- Gustav V Postal Union 50th Jubilee medal 1924

- Gustav V gold medal for Loyalty

- Gustav VI Swedish Athletics Association medal 1903

- Olympic Horseriders medal

- Swedish Police Shooting Association medal

- Stockholm Board of Trade medal

- Patriotic Society medal Gustav V

\section{United Kingdom}

- The Victoria Cross

- The George Cross 
Orders of Knighthood

- Order of the Garter

- Order of the Thistle

- Order of St Patrick

- Order of the Bath

- Order of Merit

- Order of the Star of India

- Order of St Michael and St George

- Royal Guelphic Order

- Order of the Indian Empire

- Royal Order of Victoria and Albert

- Order of the Crown of India

- Royal Victorian Order

- Order of the British Empire

- Order of the Companions of Honour

- Distinguished Service Order

- Imperial Service Order

- Royal Victorian Chain

- Royal Family Orders

- Baronet's Badge

- Knight Bachelor's Badge

- Indian Order of Merit (Military)

- Order of St John

\section{Decorations}

- Conspicuous Gallantry Cross

- Royal Red Cross

- Distinguished Service Cross

- Military Cross

- Distinguished Flying Cross

- Air Force Cross

- Order of British India

- Order of Burma

- Kaisar-i-Hind Medal

Medals for Gallant and Distinguished Service

- Union of South Africa Queen's Medal for Bravery in Gold

- Distinguished Conduct Medal

- Conspicuous Gallantry Medal

- Conspicuous Gallantry Medal (Flying)

- George Medal

- Queen's Police Medal for Gallantry

- Queen's Fire Service Medal for Gallantry

- Royal West African Frontier Force Distinguished Conduct Medal

- King's African Rifles Distinguished Conduct Medal

- Indian Distinguished Service Medal

- Union of South Africa Queen's Medal for Bravery in Silver

- Distinguished Service Medal

- Military Medal

- Distinguished Flying Medal

- Air Force Medal

- Constabulary Medal (Ireland)

- Medal for Saving Life at Sea

- Indian Order of Merit (Civil)

- Indian Police Medal for Gallantry

- Ceylon Police Medal for Gallantry

- Sierra Leone Police Medal for Gallantry

- Sierra Leone Fire Brigades Medal for Gallantry

- Colonial Police Medal for Gallantry

- Queen's Gallantry Medal 
- Royal Victorian Medal

- British Empire Medal (Civil)

- British Empire Medal (Military)

- Canada Medal

- Queen's Police Medal for Distinguished Service

- Queen's Fire Service Medal for Distinguished Service

- Queen's Volunteer Reserves Medal

- Queen's Medal for Chiefs

\section{Campaign Medals}

- Naval Gold Medal

- Army Gold Medal

- Army Gold Cross

- Waterloo Medal

- Military General Service Medal 1793-1814

- Naval General Service Medal 1793-1840

- Army of India Medal 1799-1826

- Ghunzee Medal 1839

- 1st Afghan War Medal

- Jellalabad Medal

- Defence of Kelat-I-Ghilzie Medal

- 1st China War Medal

- Scinde Campaign Medal

- Gwalior Campaign Star

- Sutlej Campaign Medal

- South African Campaign Medal

- Punjab Campaign Medal

- India General Service Medal 1854-95

- Crimean War Medal

- Baltic Medal

- Indian Mutiny Medal

- 2nd China War Medal

- New Zealand Medal

- Canada General Service Medal

- Abyssinian War Medal

- Ashantee War Medal

- Zulu and Basuto War Medal

- Afghanistan Medal

- Kabul to Kandahar Star

- Cape of Good Hope General Service Medal

- Egypt Medal 1882-89

- Khedive's Bronze Star

- North West Canada Medal 1885

- East and West Africa Medal 1887-1900

- British South Africa Company's Medal 1890-97

- Central Africa Medal 1891-98

- India Medal 1895-1902

- Ashanti Star 1895-96

- Queen's Sudan Medal 1896-97

- Khedive's Sudan Medal 1896-1908

- East and Central Africa Medal 1897-99

- Queen's South Africa Medal 1899-1902

- King's South Africa Medal 1901-02

- Queen's Mediterranean Medal 1899-1902

- Transport Medal 1899-1902

- 3rd China War Medal 1900

- Ashanti Medal 1900

- Africa General Service Medal 1902-56

- Tibet Medal 1903-04

- Zulu Rebellion Medal 1906 
- India General Service Medal 1908-35

- Sudan Medal 1910

- 1914 Star

- 1914-15 Star

- British War Medal 1914-20

- Mercantile Marine War Medal 1914-18

- Victory Medal 1914-18

- Territorial Force War Medal 1914-19

- Naval General Service Medal 1915-64

- General Service Medal 1918-64

- India General Service Medal 1936-39

- 1939-45 Star

- The Atlantic Star

- The Air Crew Europe Star

- The Africa Star

- The Pacific Star

- The Burma Star

- The Italy Star

- The France and Germany Star

- The Defence Medal

- The War Medal 1939-45

- The Korea Medal 1950-53

- UN Korea Medal

- General Service Medal 1962

- South Atlantic Medal 1982

- Gulf War Medal

- Operational Service Medal: Sierra Leone

- Operational Service Medal: Afghanistan

- Iraq Medal

\section{Polar Medals}

- Polar Medal 1818-48

- Polar Medal 1875-6

- Polar Medal 1904

Jubilee, Coronation and Durbar Medals

- Queen Victoria's Jubilee Medal 1887

- Queen Victoria's Police Jubilee Medal 1887

- Queen Victoria's Jubilee Medal 1897

- Queen Victoria's Police Jubilee Medal 1897

- Queen Victoria's Commemoration Medal 1900 (Ireland)

- King Edward VII's Coronation Medal 1902 (Civil)

- King Edward VII's Coronation Medal 1902 (Military)

- King Edward VII's Coronation Medal 1902 (Police)

- King Edward VII's Durbar 1903

- King Edward VII's Police Medal 1903 (Scotland)

- King's Visit Commemoration Medal 1903 (Ireland)

- King George V's Coronation Medal 1911

- King George V's Police Coronation Medal 1911

- King George V's Visit to Ireland Medal 1911

- King George V's Durbar Medal 1911

- King George V's Silver Jubilee Medal 1935

- King George VI's Coronation Medal 1937

- Queen Elizabeth II's Coronation Medal 1953

- Queen Elizabeth II's Silver Jubilee Medal 1977

- The Queen's Golden Jubilee Medal 2002

Efficiency and Long Service Decorations and Medals

- Victoria Faithful Service Medal

- George V Long and Faithful Service Medal 
- George VI Long and Faithful Service Medal

- Elizabeth II Long and Faithful Service Medal

- Meritorious Service Medal

- Accumulated Campaign Service Medal

- Medal for Long Service and Good Conduct (Army)

- Naval Long Service and Good Conduct Medal

- Royal Marines Meritorious Service Medal

- Royal Air Force Meritorious Service Medal

- Royal Air Force Long Service and Good Conduct Medal

- Medal for Long Service and Good Conduct (Ulster Defence Regiment)

- Police Long Service and Good Conduct Medal

- Fire Brigade Long Service and Good Conduct Medal

- Royal Canadian Mounted Police Long Service Medal

- African Police Meritorious Service Medal

- Malta Police Long Service Medal

- Cyprus Police Long Service \& Good Conduct Medal

- Ceylon Police Long Service Medal 1925-34

- Ceylon Police Long Service Medal 1950-72

- Ceylon Fire Services Long Service Medal

- Sierra Leone Police Long Service Medal

- Colonial Police Long Service and Good Conduct Medal

- Sierra Leone Fire Brigade Long Service Medal

- Colonial Fire Brigades Long Service and Good Conduct Medal

- Colonial Prison Service Medal

- Hong Kong Disciplined Services Medal

- Volunteer Officers' Decoration

- Army Emergency Reserve Decoration

- Army Emergency Reserve Medal

- Militia Long Service Medal

- Imperial Yeomanry Long Service Medal

- Indian Volunteer Forces Officers' Decoration

- Volunteer Long Service Medal for India and the Colonies

- Colonial Auxiliary Forces Officers' Decoration

- Colonial Auxiliary Forces Long Service Medal

- Territorial Decoration

- Efficiency Decoration

- Honorary Artillery Company Territorial Decoration

- Honorary Artillery Company Efficiency Decoration

- Territorial \& Army Volunteer Reserve Decoration

- Territorial Efficiency Medal

- Honourable Artillery Company Efficiency Medal

- Territorial and Army Volunteer Reserve Medal

- Special Reserve Long Service and Good Conduct Medal

- Royal Naval Reserve Decoration

- Royal Naval Volunteer Reserve Decoration

- Royal Naval Reserve Long Service and Good Conduct Medal

- Royal Naval Volunteer Reserve Long Service and Good Conduct Medal

- Royal Naval Auxiliary Sick Berth Reserve Long Service and Good Conduct Medal

- Royal Fleet Reserve Long Service and Good Conduct Medal

- Royal Naval Wireless Auxiliary Reserve Long Service and Good Conduct Medal

- Royal Naval Auxiliary Service Long Service Medal

- Air Efficiency Award

- Volunteer Reserves Service Medal

- Honourable Artillery Company Volunteer Reserve Service Medal

- Ulster Defence Regiment Medal

- Northern Ireland Home Service Medal

- Cadet Forces Medal

- Coastguard Auxiliary Service Long Service Medal

- Special Constabulary Long Service Medal

- Royal Observer Corps Medal 
- Civil Defence Long Service Medal

- Ambulance Service (Emergency Duties) Long Service and Good Conduct Medal

- Royal Fleet Auxiliary Service Medal

- Rhodesia Medal

- Royal Ulster Constabulary Service Medal

- Royal Ulster Constabulary GC Service Medal

- Northern Ireland Prison Service Medal (Prison Officers)

- Northern Ireland Prison Service Medal (Civilian Staff)

- Service Medal of the Order of St John

- Badge of the Order of the League of Mercy

- Voluntary Medical Services Medal

- Women's Royal Voluntary Service Medal

- South African Medal for War Services

- Colonial Special Constabulary Medal

- Indian Recruiting Badge (George V)

- Indian Recruiting Badge (George VI)

\section{Good Shooting Medals}

- Queen's Medal for Champion Shots (Army)

- Queen's Medal for Champion Shots (Naval)

- Queen's Medal for Champion Shots (RAF)

Independence \& Other Commemorative Medals

- Indian Independence Medal 1947

- Pakistan Independence Medal 1947

- Ceylon Armed Services Inauguration Medal

- Ceylon Police Independence Medal 1948

- Sierra Leone Independence Medal 1961

- Jamaica Independence Medal 1962

- Uganda Independence Medal 1962

- Malawi Independence Medal 1964

- Fiji Independence Medal 1970

- Papua New Guinea Independence Medal 1975

- Solomon Islands Independence Medal 1978

- Nigeria Independence Medal 1960

- Guyana Independence Medal 1966

- Gilbert Islands (Kiribati) Independence Medal 1980

- Ellis Islands (Tuvalu) Independence Medal 1980

- Zimbabwe Independence Medal 1980

- Vanuatu Independence Medal 1980

- St. Christopher, Nevis and Anguilla Independence Medal 1983

- New Zealand Commemorative Medal 1990

- Malta George Cross 50th Anniversary Commemorative Medal 1992

- Royal Falkland Islands Police Jubilee Medal 1996

- Royal Hong Kong Police/Auxiliary Police Commemoratiom Medal 1996

\section{UN}

- UN Service Medal Korea

- UN Emergency Force (Egypt) - UNEF

- UN Truce Supervision Organisation in Palestine - UNTSO

- UN Observer Group in Lebanon - UNOGIL

- UN Military Observer Group in India and Pakistan - UNMOGIP

- UN Organisations in Congo - ONUC

- UN Temporary Executive Authority in West New Guinea - UNTEA

- UN Yemen Observation Mission - UNYOM

- UN Force in Cyprus - UNFICYP

- UN Emergency Force Middle East - UNEFME

- UN Disengagement Observation Force (Golan Heights) - UNDOF

- UN Interim Force in Lebanon - UNIFIL 
- UN Iran/Iraq Military Observer Group - UNIIMOG

- UN Transition Assistance Group in Namibia - UNTAG

- UN Observer Group in Central America - ONUCA

- UN Iraq/Kuwait Observer Mission - UNIKOM

- UN Angola Verification Mission - UNAVEM

- UN Mission for the Referendum in Western Sahara - MINURSO

- UN Observer Mission in El Salvador - ONUSAL

- UN Protection Force (Yugoslavia) - UNPROFOR

- UN Advanced Mission in Cambodia - UNAMIC

- UN Transitional Authority in Cambodia - UNTAC

- UN Operations in Somalia - UNOSOM

- UN Operations in Mozambique - ONUMOZ

- UN Assistance Mission in Rwanda - UNAMIR

- UN Mission in Haiti - UNMIH

- UN Observer Mission in Georgia - UNOMIG

- UN Observer Mission in Liberia - UNOMIL

- UN Observer Mission Uganda-Rwanda - UNOMUR

- UN Mission of Observers in Tajikistan - UNMOT

- UN Mission in Bosnia-Herzegovina/International Police Task Force - UNMIBH

- UN Military Observer Mission in Prevlaka - UNMOP

- UN Transitional Administration for Eastern Slavonia - UNTAES

- UN Verification Mission in Guatemala - MINUGUA

- UN Verification Mission in the Central African Republic - MINURCA

- UN Police Support Group - UNPSG

- UN Observer Mission in Sierra Leone - UNOMSIL

- UN Interim Administration Mission in Kosovo - UNMIK

- UN Assistance Mission in East Timor - UNAMET

- UN Preventative Deployment Force - UNPREDEP

- UN Observer Mission in the Democratic Republic of the Congo - MONUC

- UN Mission in Ethiopia and Eritrea - UNMEE

- UN Special Services Medal - UNSSM

- UN Headquarters Medal - UNHQ

- Dag Hammarskjold Medal

\section{United States}

- Medal of Honor

- Marine Corps Brevet Medal

- Certificate of Merit

- Navy Cross

- Distinguished Service Cross

- Air Force Cross

- Department of Defence Distinguished Service Medal

- Department of Defence Distinguished Civilian Service Medal

- Navy and Marine Corps Distinguished Service Medal

- Department of the Navy Distinguished Civilian Service Award

- Department of the Navy Distinguished Public Service Award

- Army Distinguished Service Medal

- Air Force Distinguished Service Medal

- Coast Guard Distinguished Service Medal

- Department of Transportation Distinguished Service Medal

- NASA Medal for Exceptional Engineering Achievement

- Air Force Medal for Exceptional Civilian Service

- Silver Star

- Department of Transportation Outstanding Achievement Medal

- Defence Superior Service Medal

- Legion of Merit

- Meritorious Civilian Service Award

- Distinguished Flying Cross

- Navy/Marine Corps Medal 
- Soldier's Medal

- Airman's Medal

- Coast Guard Medal

- Gold Lifesaving Medal

- Bronze Star

- Purple Heart

- Defence Meritorious Service Medal

- Meritorious Service Medal

- Superior Civilian Service Award

- Air Medal

- Silver Lifesaving Medal

- Aerial Achievement Medal

- Department of Transportation Meritorious Achievement Medal

- Joint Services Commendation Medal

- Navy/Marine Corps Commendation Medal

- Army Commendation Medal

- Air Force Commendation Medal

- Coast Guard Commendation Medal

- Department of Transportation Bronze Medal

- Commander's Award for Civilian Service

- Defence Joint Service Achievement Medal

- Navy/Marine Corps Achievement Medal

- Army Achievement Medal

- Air Force Achievement Medal

- Department of Transportation 9-11 Medal

- Coast Guard Achievement Medal

- Achievement Medal for Civilian Service

- Coast Guard Letter of Commendation Ribbon

- Navy/Marine Corps Combat Action Ribbon

- USN Specially Meritorious Service Medal

- Navy/Marine Corps Presidential Unit Citation

- Army/Air Force Presidential Unit Citation

- Air Force Gallant Unit Citation

- Secretary of Transport Outstanding Unit Award

- Defence Joint Service Meritorious Unit Commendation

- Air Force Meritorious Unit Award

- Navy/Marine Corps Unit Commendation

- Army Valorous Unit Award

- Coast Guard Unit Commendation

- Navy/Marine Corps Meritorious Unit Commendation

- Army Meritorious Unit Commendation

- Air Force Outstanding Unit Award

- Coast Guard Meritorious Unit Commendation

- Coast Guard Meritorious Team Commendation

- Army Superior Unit Award

- Navy "E" Ribbon

- Air Force Organisational Excellence Award

- Coast Guard "E" Ribbon

- Coast Guard Bicentennial Unit Commendation

- National Security Medal

- Prisoner of War Medal

- Marine Corps Good Conduct Medal

- Navy Good Conduct Medal

- Army Good Conduct Medal

- Air Force Good Conduct Medal

- Coast Guard Good Conduct Medal

- Coast and Geodetic Survey Good Conduct Medal

- Air Force Combat Readiness Medal

- Selected Marine Corps Reserve Medal

- Naval Reserve Special Commendation Ribbon 
- Naval Reserve Meritorious Service Medal

- Army Reserve Component Achievement Medal

- Air Reserve Forces Meritorious Service Medal

- Coast Guard Reserve Good Conduct Medal

- Navy Fleet Marine Force Ribbon

- Outstanding Airman of the Year Award

- Air Force Recognition Ribbon

- Marine Corps Expeditionary Medal

- Navy Expeditionary Medal

- Navy Civil War Medal

- Army Civil War Medal

- Indian Wars Medal

- Manila Bay Medal

- West Indies Naval Campaign Medal

- Bailey Medal

- Spanish Campaign Medal

- Philippine Campaign Medal

- Navy/Marine Corps China Relief Expedition Medal

- Army China Relief Expedition Medal

- Spanish War Service Medal

- Navy/Marine Corps Philippine Campaign Medal

- Army Philippine Campaign Medal

- Philippine Congressional Medal

- Army of Cuba Occupation Medal

- Army of Puerto Rico Occupation Medal

- Army of Cuba Pacification Medal

- Peary Polar Medal

- Mexican Service Medal

- Nicaraguan Campaign Medal

- Mexican Border Service Medal

- 1st Haitian Campaign Medal (Navy)

- 1st Haitian Campaign Medal (Marine Corps

- Dominican Campaign Medal

- World War One Victory Medal

- Army of Occupation of Germany Medal

- NC-4 Medal

- Yangtze Service Medal

- Byrd Antarctic Expedition Medal 1928-30

- 2nd Byrd Antarctic Expedition Medal 1933-35

- US Antarctic Expedition Medal 1939-41

- China Service Medal

- American Defence Service Medal

- Women's Army Corps Medal

- American Campaign Medal

- Asiatic-Pacific Campaign Medal

- European-African-Middle East Campaign Medal

- World War Two Victory Medal

- Army of Occupation Medal

- Navy Occupation Service Medal

- Medal for Humane Action

- National Defence Service Medal

- Korean Service Medal

- Antarctica Service Medal

- Coast Guard Arctic Service Medal

- Armed Forces Expeditionary Medal

- Vietnam Service Medal

- Southwest Asia Service Medal

- Kosovo Campaign Medal

- Armed Forces Service Medal

- Armed Forces Civilian Service Medal 
- DIA Civilian Combat Support Medal

- Humanitarian Service Medal

- Military Outstanding Volunteer Service Medal

- Navy/Marine Corps Sea Service Deployment Ribbon

- Coast Guard Special Operation Service Ribbon

- Coast Guard Sea Service Ribbon

- Navy Arctic Service Ribbon

- Naval Reserve Sea Service Deployment Ribbon

- Navy/Marine Corps Overseas Service Ribbon

- Air Force Overseas Service Long Tour Ribbon

- Air Force Overseas Service Short Tour Ribbon

- Air Force Longevity Service Ribbon

- Air Force Military Training Instructor Ribbon

- Coast Guard Restricted Duty Ribbon

- Marine Corps Recruiting Service Ribbon

- Navy Recruiting Service Ribbon

- Coast Guard Recruiting Service Ribbon

- Coast Guard Basic Training Honour Graduate Ribbon

- Marine Corps Drill Instructor Service Ribbon

- Marine Corps Security Guard Ribbon

- Armed Forces Reserve Medal

- Marine Corps Reserve Ribbon

- Naval Reserve Medal

- Army NCO Professional Development Ribbon

- Air Force NCO Military Education Graduate Ribbon

- Army Service Ribbon

- Air Force Basic Military Training Honour Graduate Ribbon

- Army Overseas Service Ribbon

- Army Reserve Component Overseas Training Ribbon

- Air Force Small Arms Expert Ribbon

- Air Force Training Ribbon

- Navy Expert Rifle Marksman's Medal

- Navy Expert Pistol Marksman's Medal

- Coast Guard Expert Rifle Shot Medal

- Coast Guard Expert Pistol Shot Medal

- Selective Service Medal

\section{Civilian Awards}

- Arms Control and Disarmament Agency: Superior Honour Award

- Arms Control and Disarmament Agency: Meritorious Honour Award

- Defence Contract Audit Agency Distinguished Civilian Service Medal

- Defence Contract Audit Agency Meritorious Civilian Service Medal

- Department of the Army Exceptional Public Service Medal

\section{Vatikan}

- Order of Christ

- Order of the Golden Spur

- Order of Pius

- Order of St Gregory the Great

- Order of St Sylvester

- Order of the Holy Sepulchre of Jerusalem

- Cross of Honour "Pro Ecclesia et Pontifice"

- Benemerenti Medal

- Cross for the Jerusalem Pilgrims

- Papal Lateran Cross

- Mentana Cross

- 1826 Closing of the Holy Door Commemorative Medal

- Restoration of Papal Authority Commemorative Medal, 1859 
- Benemerenti Cross for the 1925 Holy Year

- Castelfidardo Medal

Compiled from: Robertson, Megan C. Medals of the World. (www.medals.org.uk). 